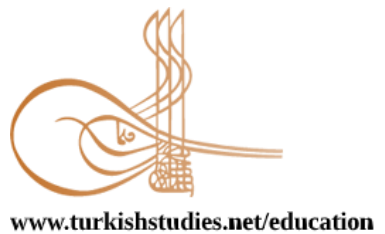

Turkish Studies - Educational Sciences

\title{
Sınıf Öğretmeni Adaylarının Sözel Beceri, Okuma ve Yazma Becerisi Geliştirme Öz Yeterliklerinin Yordayıı Bazı Değişkenler Açısından İncelenmesi*
}

\author{
Investigation of Primary School Teacher Candidates' Self-Efficacies for Developing Verbal, \\ Reading and Writing Skills in terms of Certain Predictor Variables
}

\author{
Ebru Yuvanç ${ }^{* *}-$ Ayşe Nur Kutluca Canbulat***
}

\begin{abstract}
The purpose of this study is to reveal the predictors of self-efficacy levels of primary school teacher candidates'for developing verbal, reading and writing skills in terms of their self-efficacy levels for applicating constructivist approach and their teaching motivations. The study is designed as a quantitative correlational survey research. The sample of the study consists of 374 primary school teacher candidates who enrolled at three different state universities' department of primary education in the faculty of education. Data regarding the predictors of self-efficacy levels of primary school teacher candidates'for developing verbal, reading and writing skills interms of their self-efficacies for implementating constructivist approach and their teaching motivations were gathered using Verbal skills Development Teacher Self-efficacy Scale, Reading Skills Development Teacher Self-efficacy Scale, Writing Skills Development Teacher Self-efficacy Scale, "Self Efficacy Perceptions of Teachers about the Implementation of the Constructivist Approach Scale, and Motivation to Teach Scale. According to the findings, it was concluded that the self-efficacy of primary school teacher candidates for developing verbal, reading and writing skills differed significantly according to gender, the self-efficacy of primary school teacher candidates'for developing verbal and writing skills did not differ according to their universities. However, for their self-efficacy for developing reading skills, teacher candidates who enrolled at University A statistically significantly differed from the teacher candidates who enrolled at University B, the self-efficacy of primary school teacher candidates'for developing verbal, reading and writing skills significantly differed according to their self-efficaciy for applicating constructivist approach, there was a significant correlation between the self-efficacy of primary school teacher candidates'for developing verbal, reading and writing skills and their self-efficacy for applicating the constructivist approach, there was a significant correlation between the self-efficacy of primary school teacher candidates'for developing verbal, reading and writing skills and their teaching motivations. The self-efficacy of primary school teacher candidates' constructivist approach application predicted significantly of their self-efficacy for
\end{abstract}

\footnotetext{
* Bu çalışma Ebru Yuvanç (2019)'ın Ayşe Nur Kutluca Canbulat danışmanlığında hazırlamış olduğu yüksek lisans tezinden üretilmiştir.

** Sınıf Öğretmeni, Millî Eğitim Bakanlığı, Ova İlkokulu.

Classroom Teacher, MoNE, Ova Primary School.

ORCID 0000-0003-1452-8765

ebruyuvanc2@gmail.com

**** Doç. Dr., Akdeniz Üniversitesi, Eğitim Fakültesi, Temel Eğitim Bölümü, Sınıf Eğitimi Anabilim Dalı

Assoc. Prof. Dr., Akdeniz University, Faculty of Education, Department of Primary School Education

ORCID 0000-0003-0010-7898

aysenur.canbulat@gmail.com

Cite as/ Atıf: Yuvanç, E. \& Kutluca Canbulat, A.N. (2020). Sınıf öğretmeni adaylarının sözel beceri, okuma ve yazma

becerisi geliştirme öz yeterliklerinin yordayıcı bazı değişkenler açısından incelenmesi. Turkish Studies - Education,

15(4), 3071-3097. https://dx.doi.org/10.47423/TurkishStudies.42912

Received/Geliș: 15 April/Nisan 2020

Accepted/Kabul: 27 August/Ağustos 2020

Checked by plagiarism software

Copyright $($ INTAC LTD, Turkey 
developingverbal skills, reading skill development. The dimensions which were guiding, activating the student, encouraging thinking significantly predicted the self-efficacy of teacher candidates for developing writing skills, on the other hand the alternative evaluation dimension of the constructivist approach application did not predict the self-efficacy of teacher candidates for developing writing skills, the teaching motivation of primary school teacher candidates' significantly predicted their self-efficacy for developing verbal, reading and writing skills.

Structured Abstract: Basic language skills are gained through Turkish lessons. Language teaching activities carried out in Turkish lessons enable individuals to use their mother tongue properly and in a regular manner (Canbulat et al., 2004). In order to develop their student's language skills in a desired manner, teachers need to work their field competencies, be aware of the features they have, and believe that their performance will be successful (Derbedek, 2008). This can be explained with the concept of self-efficacy based on Bandura's Social Learning Theory. Bandura (1977) defines self-efficacy as individual's judgement about his or her capacity to successfully achieve a certain level of performance. Self-efficacy, in this context, expresses the belief that the individual can successfully do a job.

Teachers' self-efficacy beliefs about skill development are influenced by their knowledge and application skills regarding the educational approach adopted by the country they are working in. The language teaching programs in Turkey are structured in accordance with the constructivist learning approach since 2004. Programs and approaches try to encompass the competencies that students are expected to gain. However, if the teachers who are supposed to apply the curriculum do not have the qualifications to develop these competencies, the education provided by them will be far from desirable and their goals will not be achieved (Özenç, 2009). It is thought that, teachers' self-efficacies that will be employed in a constructivist curriculum will determine the quality of education in general. In particular, self-efficacy beliefs will directly affect students' verbal language skills as well as their reading and writing skills.

Additionally, professional competencies of teachers and the way they perform in actual teaching processes determine the success of educational approaches and processes.

Performance of teachers is related to their level of motivation to teaching (Büyükses, 2010) and satisfaction with the profession (Karadeniz \& Yavuz, 2009). Motivation is a force that guides the individual and enables him to act in accordance with the purpose. In order to reach their goals, teachers need to have this power and reflect it on teaching environments (Güzel and Evin 2015).

Teacher candidates' self-efficacies related to developing reading, writing, and verbal skills may be influenced by the constructive approach and motivation of teachers to teach within such a paradigm.

Therefore, this study aims to find out whether prospective teachers' self-efficacies in implementing constructivist approach and their motivation to teach predict prospective teachers' self-efficacy to improve their student's language skills.

For this purpose, answers to the following questions were sought.

1) What is the level of teacher candidates' self-efficacies related to developing their student's verbal, reading and writing skills?

What is the level of teacher candidates' self-efficacies related to implementation the constructivist approach in teaching process?

What is the level of teacher candidates' motivation to teaching?

2) Do the teacher candidates' self-efficacies related to developing their student's verbal, reading and writing skills differ according to their gender or their universities?

3) Do the teacher candidates' self-efficacies related to developing their student's verbal, reading, and writing skills differ according to their self-efficacy levels of implementing the constructivist approach?

4) Do the teacher candidates' self-efficacy to implement constructivist approach predict their selfefficacies related to developing their student's verbal, reading and writing skills?

5) Do the teacher candidates' motivation to teaching predict their self-efficacies related to developing their student's verbal, reading, and writing skills? 
This study was designed as quantitative research employing relational scanning model. The study population of the research consists of third and fourth grade pre-service teachers studying at three universities in the Mediterranean Region of Turkey. The data were collected by "Verbal Skills Development Teacher Selfefficacy Scale", "Reading Skills Development Teacher Self-efficacy Scale", and "Writing Skills Development Teacher Self-efficacy Scale" which were developed by Kutluca Canbulat (2017); "Attitude Towards Constructivist Approach Scale for Teachers" which was developed by Eskici (2013) and "Teaching Motivation Scale" which was adapted to Turkish by Aytaş, Ataş Akdemir, and Seçer (2015).

According to the findings, it can be concluded that;

1) When the teacher candidates' self-efficacy scores related to developing verbal, reading and writing skills were formed by dividing into categories as low level $X_{-}^{-} 1 \mathrm{~S}$, middle level $X^{-} \pm 1 \mathrm{~S}$, and high level $X^{-}+1 S$, it was observed that the distribution were normal and the mean scores were medium.

2) Teacher candidates' self-efficacy related to developing their student's verbal, reading, and writing skills were differed significantly according to their gender. Additionally, the mean scores of female prospective teachers was higher than the mean scores male prospective teachers.

Moreover, teacher candidates' self-efficacy related to developing their student's verbal, and writing skills were differed significantly. However, their self-efficacies related to developing their student's reading skills did not differ significantly according to the universities. Tukey test, one of the post-hoc tests, was used to determine the source of the difference. According to the test results, it was observed that there was a difference between the mean scores of the students who were educated at different universities.

3. Teacher candidates' self-efficacy levels of guiding and activating the student, encouraging thinking, and alternative evaluation were differed according to teacher candidates' self-efficacy related to developing their student's verbal skills. It was observed that while the self-efficacy level of the teacher candidates' related to developing verbal, reading and writing skills were increased, the means of the sub-dimensions of constructivist approach scale sores were also increased.

4. Multiple regression analysis was conducted to determine whether the candidates' constructivist approach self-efficacy significantly predicted their self-efficacy in verbal skill development. It was observed that the relation between guiding and activating the student, encouraging thinking, and alternative assessment variables and self-efficacies of teacher candidates' related to developing verbal, reading, and writing skills were moderately significant.

It was also observed that guiding, activating the student, encouraging thinking, and alternative assessment variables explain approximately $40 \%$ of the total variance at the level of self-efficacies related to developing verbal skills. The importance order on self-efficacy levels related to developing verbal skills is guiding, encouraging thinking, activating the student and alternative evaluation. According to the significance levels of the regression coefficients, the alternative evaluation variable was not a significant predictor according to the t-test results. Guiding, activating the student, encouraging thinking and alternative assessment variables explain approximately $43 \%$ of the total variance at the level of self-efficacies related to developing reading skills. The importance order on self-efficacy levels related to developing reading skills is activating the student, guiding, encouraging thinking, and alternative evaluation. The significance levels of the regression coefficients were examined according to the t-test results, and it was seen that activating, guiding, encouraging thinking and alternative assessment variables were significant predictors of self-efficacy levels. In addition guiding, activating the student, encouraging thinking, and alternative assessment variables explain approximately $32 \%$ of the total variance at the level of self-efficacies related to developing writing skills. The importance order on self-efficacy levels related to developing reading skills is activating the student, guiding, encouraging thinking and alternative evaluation. The significance levels of the regression coefficients were examined according to the results of the t-test, and it was observed that the variables of activating and guiding the students were significant predictors of self-efficacy levels of the teacher candidates' related to developing writing skills, whereas the variables of encouraging thinking and alternative assessment were not significant predictors.

5. It was observed that there was a positive low-level relationship between teacher candidates' selfefficacy scores related to developing verbal, reading, and writing skills and their intrinsic and extrinsic motivation scores. It was also observed that the intrinsic and the extrinsic motivation scores explained approximately $10 \%$ of the total variance at the self-efficacy level related to developing verbal skills. Intrinsic 
and the extrinsic motivation scores the intrinsic and the extrinsic motivation scores explained approximately $13 \%$ of the total variance at the self-efficacy level related to developing reading skills. Intrinsic and extrinsic motivation explained approximately $11 \%$ of the total variance at the self-efficacy level related to developing writing skills.

Consequently, the significance levels of the regression coefficients were examined according to the ttest results and it was observed that the internal and external motivation variables were significant predictors of self-efficacy levels related to developing verbal, reading, and writing skills.

Keywords: Language Education, Turkish İnstruction, Developing Verbal Skills, Developing Reading Skills, Developing Writing Skills, Self-Efficacy, Teaching Motivation, Constructivist Approach.

Öz: Bu araştırmanın amacı sınıf öğretmeni adaylarının sözel beceri, okuma ve yazma becerisi geliştirme öz yeterliklerinin yapılandırmacı yaklaşımı uygulama özyeterlikleri ve öğretme motivasyonları açısından yordanma durumunu ortaya koymaktır. Bu araştırma ilişkisel tarama modelinde nicel bir çalışmadır. Araştırmanın çalışma grubu üç devlet üniversitesinin Eğitim Fakültesi Sınıf Eğitimi Anabilim Dalı 3 ve 4. sınıflarında öğrenim gören 374 öğretmen adayından oluşmaktadır. Sınıf öğretmeni adaylarının sözel beceri, okuma ve yazma becerisi geliştirme öz yeterliklerinin yapılandırmacı yaklaşımı uygulama özyeterlikleri ve öğretme motivasyonları açısından yordama durumu Sözel Beceri Geliştirme Öz Yeterlik Ölçeği, Okuma Becerisi Geliştirme Öz Yeterlik Ölçeği, Yazma Becerisi Geliştirme Öz Yeterlik Ölçeği, Öğretmenlerin Yapılandırmacı Yaklaşımı Uygulamaya Yönelik Öz Yeterlik İnanç Ölçeği, Öğretme Motivasyonu Ölçeği aracılığıyla toplanmıştır. Araştırma bulgularına göre: Sınıf öğretmeni adaylarının sözel beceri, okuma, yazma becerisi geliştirme özyeterliklerinin cinsiyete göre anlamlı farklılık gösterdiği, sınıf öğretmeni adaylarının sözel beceri geliştirme ve yazma becerisi geliştirme öz yeterliklerinin öğrenim görülen üniversiteye göre anlamlı farklılık göstermediği fakat okuma becerileri geliştirme özyeterliğinde, A Üniversitesi’nde öğrenim gören sınıf öğretmeni adaylarının B Üniversitesi’nde öğrenim gören sınıf öğretmeni adaylarınına göre, istatistiksel olarak anlamlı bir farklılık gösterdiği, sınıf öğretmeni adaylarının sözel beceri, okuma, yazma becerisi geliştirme özyeterliklerinin yapılandırmacı yaklaşımı uygulama öz yeterliklerine göre anlamlı bir farklılık gösterdiği, sınıf öğretmeni adaylarının sözel beceri, okuma ve yazma becerisi geliştirme özyeterlikleri ile yapılandırmacı yaklaşımı uygulama öz yeterlikleri arasında anlamlı bir ilişki olduğu, sınıf öğretmeni adaylarının sözel beceri, okuma ve yazma becerisi geliştirme özyeterlikleri ile öğretme motivasyonları arasında anlamlı bir ilişki olduğu söylenebilir. Sınıf öğretmeni adaylarının yapılandırmacı yaklaşımı uygulama öz yeterliklerinin sözel beceri, okuma becerisi geliştirme öz yeterliklerini anlamlı şekilde yordadığ yapılandırmacı yaklaşımı uygulama alt boyutlarından alternatif değerlendirme boyutunun yazma becerisi geliştirme öz yeterliğini yordamadığı, rehberlik etme, öğrenciyi aktifleştirme, düşünmeye teşvik boyutlarının yazma becerisi geliştirme öz yeterliklerini anlamlı şekilde yordadığı, sınıf öğretmeni adaylarının öğretme motivasyonlarının sözel beceri, okuma ve yazma becerisi geliştirme öz yeterliklerini anlamlı şekilde yordadığı söylenebilir.

Anahtar Kelimeler: Dil Eğitimi, Türkçe Öğretimi, Sözel Beceri Geliştirme, Okuma Becerisi Geliștirme, Yazma Becerisi Geliştirme, Özyeterlik, Öğretme Motivasyonu, Yapılandırmacı Yaklaşım.

\section{Giriş}

Çağdaş toplumların eğitim sistemleri, öğrenme becerilerini geliştiren, öğrendikleriyle gerçek yaşam problemlerini çözebilen ve bilgiyi ezberlemek yerine bilgiyi farklı zekâ alanlarını kullanarak yeniden üretebilen bireyler yetiştirmeyi amaçlamaktadır. Eğitim sistemlerinin amaçlarını istenilir nitelikte gerçekleştirilmesinde eğitim programları, öğretmenler, fiziki koşullar, eğitim materyalleri gibi birçok unsur etkilidir. Ancak öğretmenler, öğrencilerin yaşamında bütünüyle etkili olmaları açısından bu unsurlar arasında ön plana çıkmaktadır (Demirtaş, Cömert \& Özer, 2011). Eğitim ve öğretim etkinliklerinin en iyi biçimde planlanması ve yürütülmesi iyi yetişmiş öğretmenlerle mümkün olabilir. Çünkü öğretmenler Üstüner(2006)'in belirttiği gibi sınıf içi sınıf dışı etkinlikleri planlayıp ve uygulamakta böylece de eğitim sistemlerinin amaçlarına yönelik ilk ve en önemli adımları atmaktadırlar. 
Öğrencilerin yaşadığı çağın becerilerine sahip olabilmesi ve bu becerileri etkin bir şekilde kullanabilmesi için öğretmenin öğrencide bütünsel bir etki oluşturması beklenmektedir. Formal eğitimin ilk uygulayıcısı ve öğrencide gelişmesi istenen özelliklerin temelini atan ve böylece de öğrencinin bütünsel gelişimine hizmet eden ilk öğretmen sınıf öğretmenidir. Senemoğlu (1992) sınıf öğretmenlerinin, bireyin bilişsel gelişim açısından çok önemli bir dönem olan 5-11 yaşlarındaki çocukların bilişsel gelişimini destekleyen ve yirmi birinci yüzyıl becerileri olan araştırma sorgulama, eleştirel bakış açısı kazanma gibi becerilerinin gelişimini hızlandıran öğretmenler olduğunu ifade etmiştir.

Sınıf öğretmenlerinin öğrencilerin bütünsel gelişimine hizmet edecek görev sorumlulukları yerine getirebilmeleri ve eğitim öğretim etkinliklerinin başarıya ulaşması için birtakım yeterliklere sahip olmaları beklenmektedir. Çünkü öğretmen yeterliliği etkili bir eğitim süreci için çok önemli bir faktördür (Büyükkaragöz, 1998). Milli Eğitim Bakanlı̆̆ 1 "mesleki bilgi", "mesleki beceri", "tutum ve değerler" olmak üzere birbirini tamamlayan üç yeterlik alanıyla, 11 yeterlik 65 yeterlik göstergesi ile öğretmenlerin sahip olmaları beklenen yeterlikleri açıklamıştır. Bütünsel olarak yayınlanan metinde özel alan yeterliklerine yer verilmezken her öğretmenin alanına ilişkin yeterlikleri taşıması gerektiği belirtilmiştir. Alan bilgisi yeterliklerinin öğretimin kalitesinin belirleyicisi olması beklenmektedir (MEB,2017).

Öğretmenlerin yeterliklerini etkili bir şekilde uygulamaya taşıyabilmesinin ise dil becerilerine ve bu becerileri sınıf içinde etkin bir şekilde kullanabilmelerine bağlı olduğu söylenebilir. Öğretmen dil becerileri aracılığıyla anlatmak istediklerini anlatabilir ya da öğrenciden gelen mesajları anlamlandırabilir. Aynı zamanda dil becerileri gelişmiş bir öğretmen öğrencilerin dil becerilerini geliştirmelerine yardımcı olabilir. Öğrencilerin iyi yetişmiş bir birey ve aynı zamanda etkin bir vatandaş olabilmesinin en önemli yollarından biri dil becerilerini doğru ve istenilir biçimde kullanmaktan geçmektedir. Dolayısıyla öğrencilerin dinleme ve konuşma becerileri bir başka deyişle sözel dil becerileri ile okuma, yazma becerilerinin geliştirilmesi eğitim sisteminin en öncelikli hedefi olarak görülebilir. Çünkü bireylerin akademik olarak performanslarını yansıtabilmeleri ve çevreleriyle iletişim kurabilmeleri anlama, kavrama, ilişki kurma, yorumlama, analiz, sentez vb. üst düzey zihinsel becerilerini etkin olarak kullanmaları ile ilişkilidir (Göçer, 2010). Zihinsel becerilerin etkin olarak kullanılabilmesi ise temel dil becerilerinin gelişimi ile yakından ilişkilidir.

Temel becerileri bireyin çevresinde olup bitenleri anlamasına hizmet eden alıcı dil becerileri olarak ifade edilen anlama becerileri (okuma, dinleme)ile anlatabilmesine olanak taniyan ve ifade edici dil becerileri olarak ifade edilen, anlatım becerilerinden (konuşma, yazma) oluşmaktadır (Kavcar vd.1998). Anlama becerilerini oluşturan okuma ve dinleme becerileri bireyin kendisi dışındaki bireylerin duygu ve düşüncelerinin anlaşılmasını sağlayan becerilerdir. Anlatma becerilerini ifade eden konuşma ve yazma becerisi ise bireyin kendi duygu, düşünce ve izlenimlerini aktarabildiği becerilerdir.

Anadildeki temel dil becerileri konuşma, dinleme (sözel beceriler), okuma ve yazma ilköğretim kurumlarında Türkçe dersleriyle kazandırılır. Türkçe derslerinde gerçekleştirilen dil öğretimine yönelik etkinlikler bireylerin anadillerini düzgün ve kurallı bir şekilde kullanmalarını sağlamaktadır (Canbulat vd.2004). Güneyli (2007)' nin belirttiği gibi birey kendi dilini etkin kullandığı noktada diğer becerileri gelişir. Bu nedenle Türkçe öğretimi ile ilgili becerilere ilişkin geliştirmesi istenen yeterlikler sınıf öğretmenleri için oldukça önemlidir.

Dil becerileri açısından sözlü iletişimin bir parçası olan dinleme becerisi; dış dünyadan verilen mesajı algılama, anlamlandırma, yorumlama, değerlendirme gibi bilişsel beceriler ile bu becerileri kullanarak iletişim kurma gibi sosyal yeterliliklerini gerektiren çok önemli bir beceridir (Tabak \& Göçer, 2014). Çünkü iletişim dinleme ile başlamaktadır. Konuşma becerisi ise dinlediklerini, dış dünyadan edindiklerini aktarabilmenin başka bir anlatımla kendini ifade etmenin en bilinen(Yelok \& Sallabaş, 2009) ve iletişim sürecinde en çok kullanılan yoludur. Okuma becerisi; 
yazılı metinlerdeki anlamların çözümlenmesi ve metin aracılığıla aktarılmak istenen bilgilerin bireyin kendisinde var olan ön bilgilerle ilişkilendirerek yeni anlamlar oluşturmasına olanak veren aktif bir süreç olarak ele alınmış ve bireyin, sahip olduğu bilgi ve becerilerini geliştirmenin bir yolu olarak ifade edilmiştir (Demirel, 1999). Yazma becerisi ise anlatılmak isteneni en açık ve doğru biçimde okuyucuya iletebilecek kelimelerin seçimi ile yazının mekanik özelliklerinin doğru kullanılması yoluyla ana düşüncenin okuyucuya en anlaşılır şekilde ulaşmasını sağlayan birçok alt becerinin kullanılması ile ilişkili bir beceridir. Öğrencinin yazacağı konuya, yazacağı hedef kitleye uygun olarak yazma amacını belirginleştireceği bir aşama olarak yazma konusuna karar vermesiyle başlayan, hazırlık, planlama, düzenleme, düzeltme ve paylaşma gibi aşamalardan oluşan bir süreci gerektirir. Yazının çerçevesinin belirlenerek, cümleler arasında akıcılığı, tutarlılığ ve bağdaşıklığı ise yazma becerisine sahip bireylerin yazarken dikkat etmesi gereken özellikler arasında sayılabilir (Sever \& Memiş, 2013).

Öğretmenlerin bu becerileri istenilir nitelikte geliştirebilmeleri için alan yeterliklerini işe koşmaları, sahip oldukları özelliklerin farkında olmaları ve gerçekleştirecekleri öğretimin başarılı olacağına inanmaları gerekmektedir (Derbedek,2008). Bandura' nın Sosyal Öğrenme Kuramı'na dayanan öz yeterlik kavramı bu durumu açıklayabilir. Bandura (1977) özyeterliği bireyin belli bir performans düzeyini başarma kapasitesine ilişkin yargısı olarak tanımlar. Özyeterlik bu bağlamda bireyin bir işi yapabileceğine olan inancını ifade eder.

Öğretmenlerin beceri geliştirmeye yönelik özyeterlik inancı ülkenin benimsediği eğitim felsefesi ve eğitim anlayışıyla ilişkilidir. Türkiye 'de 2004 yılında hazırlanan Türkçe (1-5.Sınıflar) Öğretim Programı'nda öğrenmeyi merkeze alarak insan beyninin aktif kullanımını önemseyen, dil ve zihinsel becerileri üst seviyelerde geliştirme amacında olan yapılandırı dil öğretimi yaklaşımı temel alınmıştır (Güneş, 2009). Bu yaklaşımla birlikte öğretmenlerin öğrenme öğretme sürecinin öğrenci merkezli olarak gerçekleştirilmesinin gerekliliği ortaya konmuştur. 2015 yılında uygulamaya başlanan Türkçe (1-8.Sinıflar) Öğretim Programı'nda yapılandırmacı yaklaşımın uygulanmasına devam edilmiş, 2018 Türkçe Öğretim Programı'nda ürettiği bilgiyi işlevsel olarak kullanabilen, problem çözebilen, eleştirel düşünen, girişimci, kararl1, iletişim sürecinde empati yapabilen ve kültürel gelişime katkı sağlayabilecek bireylerin yetiştirilmesi amaçlanmıştır (MEB, 2018). Beceri geliştirme, eğitim sistemimizin felsefesini oluşturan yapılandırmacıeğitim paradigmasının yapı taşıdır (Kurudayığlu ve Kana, 2013). Yapılandırmacı yaklaşımla birlikte geleceğin insanını yetiştirmek için hangi becerilere ağırlık verilmesi gerektiği konusunda yapılan uzun süreli araştırmaların sonucunda geleceğin bütün eğitim çalışmalarının merkezine, dil ve zihinsel becerilerin alınması gerektiği, ortaya çıkmıştır. Bu sonuçlar birçok gelişmiş ülkenin eğitim programlarında yeniliğe gitmesini sağlamıştır (Güneş,2007).

Programlar ve yaklaşımlar öğrencilerin sahip olması beklenen özelliklerin çerçevesini en iyi şekilde çizmeye çalışırlar. Ancak öğretim programlarını uygulayacak öğretmenler bu özellikleri geliştirebilmeye yönelik yeterliliklere sahip değillerse yapılan eğitim istenilir nitelikte olmaktan uzaklaşacak ve hedeflerine ulaşılamayacaktır (Özenç,2009). Öğretmenlerin yapılandırmacı yaklaşımı uygulama özyeterliklerinin genel olarak eğitimin kalitesini belirleyeceği özelde ise öğrencilerin sözel dil becerilerini, okuma ve yazma becerilerini doğrudan etkileyeceği düşünülmektedir. Benimsenen öğrenme öğretme yaklaşımı öğrencinin hangi özelliklerinin nasıl şekillendirileceğinin çerçevesini çizer. Bu nedenle öğrencinin dil becerilerinin nasıl geliştirileceği de benimsenen yaklaşımın etkisindedir. Öğretmen bireyi merkeze alan yapılandırmacı öğrenme yaklaşımını ne kadar uygulamaya taşırsa öğrencinin dil becerilerinin de o düzeyde gelişeceği düşünülebilir.

Öğretmenlik insani duyarlıklar bakımından yetkinlik isteyen bir meslektir. Değişen eğitim sistemlerinde benimsenen eğitim anlayışının ne kadar işleyeceği öğretmen yeterliklerine ve öğretmenin göstereceği performansa bağlıdır. Öğretmenin göstereceği performans ise eğitim ve 
öğretime ilişkin motivasyon düzeyleri (Büyükses,2010) ve meslekten aldığı doyum ile ilişkili olduğu söylenebilir (Karadeniz ve Yavuz, 2009). Motivasyon, bireyi yönlendiren, amaç doğrultusunda hareket etmesini sağlayan bir güçtür. Öğretmenlerin hedeflerine ulaşabilmeleri için bu güce sahip olmaları ve eğitim öğretim ortamlarına yansıtabilmeleri gerekir (Güzel ve Evin 2015).

Sınıf öğretmeni adaylarının sözel beceri, okuma ve yazma becerileri geliştirme özyeterliklerinin benimsenen yapılandırmacı yaklaşımdan, öğretmen adayının öğrencilerinin dil becerilerini geliştirebileceğine dair inançlarından ve öğretme motivasyonlarından etkileneceği düşünülmektedir. Bu nedenle bu araştırmada öğretmen adaylarının dil becerilerine ilişkin özyeterlik düzeylerinin yordayıcılarının ortaya konulmasının öğretmen yetiştirme sürecine yön verebileceği düşüncesi ile öğretmen adaylarının yapılandırmacı yaklaşımı uygulama öz yeterliklerinin ve öğretme motivasyonlarının sözel beceri, okuma ve yazma becerileri geliştirme özyeterliklerini yordama durumları ortaya konulmaya çalışı1mıştır.

Sınıf öğretmeni adaylarının sözel beceri, okuma ve yazma becerilerini geliştirme öz yeterlik düzeylerini cinsiyet ve öğrenim görülen üniversite değişkenleri ile yapılandırmacı yaklaşımı uygulama özyeterlikleri ve öğretme motivasyonları açısından inceleme amacıyla aşağıdaki sorulara cevap aranmıştır.

Sınıf öğretmeni adaylarının;

1) Sözel beceri geliştirme öz yeterlikleri ne düzeydedir? Okuma becerisi geliştirme öz yeterlikleri ne düzeydedir? Yazma becerisi geliştirme öz yeterlikleri ne düzeydedir? Yapılandırmacı yaklaşım uygulama öz yeterlikleri ne düzeydedir? Öğretme motivasyonları ne düzeydedir?

2) Sözel beceri geliştirme öz yeterlikleri, cinsiyete ve öğrenim gördüğü üniversiteye göre farklılaşmakta mıdır? Okuma becerisi geliştirme öz yeterlikleri, cinsiyete ve öğrenim gördüğü üniversiteye göre farklılaşmakta mıdır? Yazma becerisi geliştirme öz yeterlikleri, cinsiyete ve öğrenim gördüğü üniversiteye göre farklılaşmakta mıdır?

3) Sözel beceri geliştirme öz yeterlik düzeyleri, yapılandırmacı yaklaşımı uygulama öz yeterlik düzeylerine görefarklılaşmakta mıdır? Okuma becerisi geliştirme öz yeterlik düzeyleri, yapılandırmacı yaklaşımı uygulama öz yeterlik düzeylerine görefarklılaşmakta mıdır? Yazma becerisi geliştirme öz yeterlik düzeyleri, yapılandırmacı yaklaşımı uygulama öz yeterlik düzeylerine göre farklılaşmakta mıdır?

4) Yapılandırmacı yaklaşım uygulama özyeterlikleri, sözel beceri geliştirme özyeterliklerini yordamakta mıdır? Yapılandırmacı yaklaşım uygulama özyeterlikleri, okuma becerisi geliştirme özyeterliklerini yordamakta mıdır? Yapılandırmacı yaklaşım uygulama özyeterlikleri, yazma becerisi geliştirme özyeterliklerini yordamakta mıdır?

5) Öğretme motivasyonları, sözel beceri geliştirme özyeterliklerini yordamakta mıdır? Öğretme motivasyonları, okuma becerisi geliştirme özyeterliklerini yordamakta mıdır? Öğretme motivasyonları, yazma becerisi geliştirme öz yeterliklerini yordamakta mıdır?

\section{Yöntem}

\section{Araştırma Modeli}

Sınıf öğretmeni adaylarının yapılandırmacı yaklaşımı uygulama özyeterlikleri ve öğretme motivasyonlarının sözel beceri, okuma ve yazma becerilerini geliştirme özyeterliklerini yordama durumunu çeşitli değişkenlere göre incelemenin amaçlandığı bu çalışma nicel araştırma metodolojisine uygun olarak ilişkisel tarama modeli ile desenlenmiştir. Tarama araştırmalarında, katılımcıların görüşülerine göre genel bir yargıya ulaşma hedeflenir (Büyüköztürk vd.,2014).İlişkisel tarama modeli, iki veya daha fazla değişken arasında birlikte bir değişimin varlığını sorgulayarak böyle bir değişim varsa bu değişimin yönü ve düzeyini bulmayı hedefleyen araştırma modelidir (Karasar, 2005). 
Araştırmanın çalışma evrenini, 2017-2018 eğitim öğretim yılı içinde kolay ulaş1labilir örnekleme yöntemiyle belirlenen Akdeniz Bölgesi’nde üç üniversitenin SınıfEğitimi Ana Bilim Dalı üçüncü ve dördüncü sınıflarında öğrenim gören öğretmen adayları oluşturmaktadır. Araştırmada, bütün çalışma evrenine ulaşılmak istenmiştir, ancak katılımcıların gönüllülük esasına uygun olarak 374 öğretmen adayı çalışma grubuna dahil edilmiştir. Üniversiteler A Üniversitesi, B Üniversitesi ve C Üniversitesi olarak kodlanmıştır. 374 katılımcıya ait cinsiyet(kadın $n=288$, erkek $n=86$ ) ve üniversite değişkenlerine ( $\mathrm{AÜ}=143, \mathrm{BÜ}=74, C \ddot{U}=157)$ göre belirlenmiş betimsel istatistik sonuçlara göre grubun çoğunlukla kadın bireylerden oluştuğu (\%77) görülmüştür. 3 farklı üniversiteden toplanan verilerde A Üniversitesi ve C Üniversitesi'nde eğitimine devam eden bireylerin birbirine yakın sayıda olduğu, B Üniversitesi’ndeki eğitim görmekte olan bireylerin sayısının daha az (\%19.8) olduğu görülmüştür.

\section{Veri Toplama Araçları}

Araştırma verileri, Kutluca Canbulat (2017)'ın geliştirmiş olduğu “Sözel Beceri Geliştirme Öğretmen Özyeterlik Algısı Ölçeği” (SBGÖÖ), "Okuma Becerisi Geliştirme Öğretmen Özyeterlik Alg1s1 Ölçeği”" (OBGÖÖ) ve "Yazma Becerisi Geliştirme Öğretmen Özyeterlik Algısı Ölçeği" (YBGÖÖ) ve Eskici (2013)'nin geliştirmiş olduğu "Yapılandırmacı Yaklaşımı Uygulama Özyeterlik Ölçeği” (YYUÖÖ) ile Ayık, Ataş Akdemir \& Seçer (2015)'in Türkçe'ye uyarlamış oldukları "Öğretme Motivasyonu Ölçeği”" (ÖMÖ) aracılığıyla toplanmıştır.

\section{Verilerin Analizi}

Öğretmen adaylarından elde edilen verilerin analizinde ilk olarak tek yönlü uç değer taraması yap1lıp kesme noktas1 \pm 3 (Raykov \& Marcoulides, 2008) olarak belirlendikten sonra kesme noktasının dışında kalan 24 değer analize dahil edilmemiştir. Verilerin normalliği çarpıklık-basıklık katsayıları ile kontrol edilmiştir. Çarpıklık-basıklık katsayıları için kesme noktası olarak $\mp 1$ aralığ kabul edilmiştir. Verilerin normal dağılım gösterdiği belirlenerek parametrik yöntemlerle analizler gerçekleştirilmiştir. Regresyon analizi için de değişkenlere ait basıklık-çarpıklık katsayıları incelendiğinde elde edilendeğerler \pm 1 aralığına yakın değerler olduğu için verilerin normalden çok sapma göstermediği ve normale yakın bir dağılım gösterdiği kabul edilmiştir. VIF değerlerinin ise tümünün 10'un altında olduğu tespit edilmiştir. Tüm varsayımların karşılandığıtespit edilerek analizler yapılmıştır. Araştırmanın birinci alt problemi için; Sınıf öğretmeni adaylarının sözel beceri geliştirme, okuma becerisi geliştirme ve yazma becerisi geliştirme öz yeterlik düzeyleri, yapılandırmacı yaklaşımı uygulamaya yönelik öz yeterlik düzeyleri ve öğretme motivasyon düzeylerine ilişkin betimsel değerler incelenmiş, sözel beceri geliştirme, okuma ve yazma becerisi geliştirme öz-yeterlik düzeyleri düşük düzey $\bar{X}$-1S altında, orta düzey $\bar{X} \pm 1 \mathrm{~S}$ aralı̆̆ ve yüksek düzey $\bar{X}+1 \mathrm{~S}$ üzerindeki puanlar olmak üzere kategorilerler oluşturulmuştur. Araştırmanın ikinci alt problemi için; Sınıf ögretmeni adaylarının sözel beceri geliştirme, okuma becerisi geliştirme ve yazma becerisi geliştirme özyeterliklerinin cinsiyetlerine göre anlamlı bir farkl1lık gösterip göstermedikleri bağımsız gruplar için t-testi ile öğrenim gördükleri üniversiteye göre anlamlı bir farklılık gösterip göstermedikleri tek faktörlü ANOVA ile analiz edilmiştir. Anlamlı çıkan sonuçlar için farklılığın kaynağını belirlemek için post-hoc testlerinden Tukey testi yapılmıştır. Araştırmanın üçüncü alt problemi için; rehberlik etme, öğrenciyi aktifleştirme, düşünmeye teşvik ve alternatif değerlendirme düzeylerinin sözel beceri geliştirme öz yeterlik düzeylerine göre anlamlı bir farklılık gösterip göstermediği tek faktörlü ANOVA ile analiz edilmiştir. Anlamlı çıkan sonuçlar için farklılı̆̆ın kaynağını belirlemek için post-hoc testlerinden Tukey testi yapılmıştır. Araştırmanın dördüncü problemi için bireylerin yapılandırmacı yaklaşım uygulama öz yeterliklerinin sözel beceri geliştirme öz yeterliklerini anlamlı şekilde yordayıp yordamadığını belirlemek amacıyla çoklu regresyon analizi yapılmış ve duyarlılığın yordanmasına ilişkin regresyon denklemi şöyle kurulmuştur. 
Sözel beceri geliştirme öz yeterliği $=32.714+0.461 *($ Rehberlik etme $)+0.456 *$ (düşünmeye teşvik) $+0.324 *$ (öğrenciyi aktifleştirme) $-0.308 *$ (Alternatif değerlendirme)

Adayların yapılandırmacı yaklaşımı uygulama öz yeterliklerinin okuma becerisi geliştirme öz yeterliklerini anlamlı şekilde yordayıp yordamadığını belirlemek amacıyla çoklu regresyon analizi yapılmış, duyarlılığın yordanmasına ilişkin regresyon denklemi şu şekilde kurulmuştur.

Okuma becerisi geliştirme öz-yeterliği $=25.467+0.272 *($ Rehberlik etme) $\quad+$ $0.325 *$ (düşünmeye teşvik) $+0.224 *$ (öğrenciyi aktifleştirme) $-0.208 *$ (Alternatif değerlendirme)

Bireylerin yapılandırmacı yaklaşım uygulama öz yeterliklerinin yazma becerisi geliştirme öz yeterliklerini anlamlı şekilde yordayıp yordamadığını belirlemek amacıyla çoklu regresyon analizi yapılmış, duyarlılığın yordanmasına ilişkin regresyon denklemi şu şekilde kurulmuştur.

Yazma becerisi geliştirme öz yeterliği $=19.591+0.172 *($ Rehberlik etme $) \quad+$ 0.205*(Düşünmeye teşvik) +0.146* (Öğrenciyi aktifleştirme)-0.097 *(Alternatif değerlendirme).

Araştırmanın beşinci problemi için; bireylerin öğretme motivasyonlarının sözel beceri geliştirme öz yeterliklerini anlamlı şekilde yordayıp yordamadığını belirlemek amacıyla çoklu regresyon analizi yapılmış, duyarlılığın yordanmasına ilişkin regresyon denklemi aşağıda verilmiştir. motivasyon)

Sözel beceri geliştirme öz yeterliği $=59.598-0.248 *($ İçsel motivasyon $)+0.619 *($ Dişsal

Bireylerin öğretmemotivasyonlarının okuma becerisi geliştirme öz yeterliklerini anlamlı şekilde yordayıp yordamadığını belirlemek amacıyla çoklu regresyon analizi yapılmıştır. Yapılan çoklu regresyon analizine göre, duyarlılığın yordanmasına ilişkin regresyon denklemi aşağıda verilmiştir.

Okuma becerisi geliştirme öz-yeterliği $=43.539-0.243 *($ İçsel motivasyon $)+0.476 *(\mathrm{D}$ şsal motivasyon)

Bireylerin öğretme motivasyonlarının yazma becerisi geliştirme öz yeterliklerini anlamlı şekilde yordayıp yordamadığını belirlemek amacıyla çoklu regresyon analizi yapılmıştır. Yapılan çoklu regresyon analizine göre, duyarlılığın yordanmasına ilişkin regresyon denklemi aşağıda verilmiştir.

Yazma becerisi geliştirme öz yeterliği $=30.869-0.131 *($ İçsel motivasyon $)+0.328 *($ Dişsal motivasyon).

\section{Bulgular}

1) Araştırmanın Birinci Alt Problemine İliş̧kin Bulgular

Sınıf öğretmeni adaylarının sözel beceri geliştirme, okuma becerisi geliştirme ve yazma becerisi geliştirme özyeterlik düzeyleri, yapılandırmacı yaklaşımı uygulamaya yönelik özyeterlik düzeyleri ve öğretme motivasyon düzeylerine ilişkin betimsel değerler Tablo 1'de verilmiştir. 
Tablo 1: Sınıf Öğretmeni Adaylarının Özyeterlik ve Motivasyon Düzeylerine Ait Betimsel Sonuçlar

\begin{tabular}{|c|c|c|c|c|c|c|c|}
\hline & & $\bar{X}$ & Max. & Min. & $\mathbf{S}$ & Çarpıklık & Basıklık \\
\hline $\begin{array}{l}\text { Sözel } \\
\text { Geliştirme }\end{array}$ & Beceri & 67.72 & 80 & 41 & 7.43 & -0.172 & -0.304 \\
\hline $\begin{array}{l}\text { Okuma } \\
\text { Geliştirme }\end{array}$ & Becerisi & 48.87 & 55 & 35 & 4.73 & -0.396 & -0.710 \\
\hline $\begin{array}{l}\text { Yazma } \\
\text { Geliştirme }\end{array}$ & Becerisi & 35.18 & 40 & 20 & 3.63 & -0.503 & -0.032 \\
\hline Rehberlik & & 37.23 & 45 & 18 & 5.23 & -0.541 & 0.235 \\
\hline $\begin{array}{l}\text { Öğrenciyi } \\
\text { Aktifleştirn }\end{array}$ & & 34.10 & 40 & 16 & 4.60 & -0.847 & 0.795 \\
\hline Düşünmey & Teşvik & 28.07 & 35 & 14 & 4.16 & -0.554 & 0.380 \\
\hline $\begin{array}{l}\text { Alternatif } \\
\text { Değerlendi }\end{array}$ & & 19.590 & 25 & 8 & 3.36 & -0.583 & 0.280 \\
\hline Dişsal Mot & asyon & 17.20 & 30 & 6 & 5.65 & 0.089 & -0.585 \\
\hline İçsel Motiv & syon & 67.72 & 30 & 6 & 4.96 & -0.481 & 0.188 \\
\hline
\end{tabular}

Sınıf öğretmeni adaylarının özyeterlik ve motivasyon düzeylerine ait betimsel sonuçlarda çarpıklık ve basıklık katsayılarına bakıldığında dağılımın normal olduğu görülmektedir. Sözel beceri, okuma becerisi, yazma becerisi geliştirme özyeterlikleri ile yapılandırmacı yaklaşımı uygulama özyeterliklerine ait rehberlik etme, öğrenciyi aktifleştirme, düşünmeye teşvik ve alternatif değerlendirme boyutlarının ve öğretme motivasyonunun alt boyutları olan içsel ve dışsal motivasyona ait ortalamaların orta düzeyde olduğu görülmektedir. Sözel beceri geliştirme, okuma becerisi geliştirme ve yazma becerisi geliştirme düzeylerine ait oluşturulan kategoriler Tablo 2'de gösterilmektedir.

Tablo 2: Sözel Beceri Geliştirme, Okuma Becerisi Geliştirme ve Yazma Becerisi Geliştirme Özyeterlik Düzeyleri

\begin{tabular}{|c|c|c|c|c|c|c|}
\hline & $\begin{array}{l}\text { Sözel } \\
\text { Geliștirme }\end{array}$ & Beceri & $\begin{array}{l}\text { Okuma } \\
\text { Geliștirme }\end{array}$ & Becerisi & $\begin{array}{l}\text { Yazma } \\
\text { Geliștirme }\end{array}$ & Becerisi \\
\hline Düşük Düzey & 60.29 ve altı & & 44.14 ve altı & & 31.55 ve altı & \\
\hline Orta Düzey & $75.15-60.29$ & & $53.6-44.14$ & & $38.81-31.55$ & \\
\hline Yüksek Düzey & 75.15 ve üzere & & 53.6 ve üzere & & 38.81 ve üzere & \\
\hline
\end{tabular}

Tablo 2' de sınıf öğretmeni adaylarının sözel beceri geliştirme, okuma becerisi geliştirme ve yazma becerisi geliştirme puanları düşük düzey $\overline{\boldsymbol{X}}$-1S altında, orta düzey $\overline{\boldsymbol{X}} \pm 1 \mathrm{~S}$ aralığ ve yüksek düzey $\overline{\boldsymbol{X}}+1 \mathrm{~S}$ üzerindeki puanlar olmak üzere düzeylere ait katagoriler oluşturulmuştur.

2) Araştırmanın İkinci Alt Problemine İlişkin Bulgular

Sınıf öğretmeni adaylarının sözel beceri geliştirme, okuma becerisi geliştirme ve yazma becerisi geliştirme özyeterliklerinin cinsiyetlerine göre anlamlı bir farklılık gösterip göstermediği bağımsız gruplar için t-testi ile belirlenmeye çalışılmış ve analiz sonuçları Tablo 3 'te gösterilmiştir. 
Tablo 3: Sözel Beceri Geliştirme, Okuma Becerisi Geliştirme ve Yazma Becerisi Geliştirme Özyeterliklerinin Cinsiyetlerine Göre T-Testi Sonuçları

\begin{tabular}{|c|c|c|c|c|c|c|c|c|}
\hline & Grup & $\mathbf{N}$ & $\overline{\boldsymbol{X}}$ & $\mathbf{S}$ & Sd & $\mathbf{T}$ & $\mathbf{P}$ & $\begin{array}{l}\text { Cohen } \\
\text { d }\end{array}$ \\
\hline Sözel Beceri & Erkek & 86 & 66.06 & 7.42 & & & & \\
\hline Geliştirme & Kadın & 288 & 68.21 & 7.38 & 372 & -2.373 & $0.018^{*}$ & 0.24 \\
\hline Okuma Becerisi & Erkek & 86 & 33.90 & 4.07 & & -3.793 & $0.000 * *$ & 0.39 \\
\hline Geliştirme & Kadın & 288 & 35.56 & 3.41 & $3 / 2$ & -3.193 & $0.000^{4}$ & 0.39 \\
\hline $\begin{array}{l}\text { Yazma Becerisi } \\
\text { Geliştirme }\end{array}$ & $\begin{array}{l}\text { Erkek } \\
\text { Kadın }\end{array}$ & $\begin{array}{l}86 \\
288\end{array}$ & $\begin{array}{l}47.19 \\
49.38\end{array}$ & $\begin{array}{l}4.96 \\
4.55\end{array}$ & 372 & -3.840 & $0.000 * *$ & 0.20 \\
\hline
\end{tabular}
$* \mathrm{p}<0.05, * * \mathrm{p}<0.001$

Tablo 3 incelendiğinde, adayların sözel beceri geliştirme özyeterliklerinin cinsiyetlerine göre anlamlı şekilde farklılaştığ 1 görülmektedir $\left(\boldsymbol{t}_{(\mathbf{3 7 2})}=-2.373, \mathrm{p}=0.015\right)$. Ortalamalar incelendiğinde kadınların ortalamasının $(\overline{\boldsymbol{X}}=68.21)$ erkeklerin ortalamasından daha yüksek olduğu $(\overline{\boldsymbol{X}}=66.06)$; ortalamadaki söz konusu bu fark için hesaplanan etki büyüklüğünün de orta düzeyde olduğu anlaşılmaktadır.

Öğretmen adaylarının okuma becerisi geliştirme özyeterliklerinin cinsiyetlerine göre anlamlı şekilde farklılaştığı görülmektedir $\left(\boldsymbol{t}_{(\mathbf{3 7 2})}=-3.793, \mathrm{p}=0.000\right)$. Ortalamalar incelendiğinde kadınların ortalamasının $(\overline{\boldsymbol{X}}=35.56)$ erkeklerin ortalamasından daha yüksek olduğu $(\overline{\boldsymbol{X}}=33.9)$; ortalamadaki söz konusu bu fark için hesaplanan etki büyüklüğünün de orta düzeyde olduğu anlaşılmaktadır.

Adayların yazma becerisi geliştirme özyeterliklerinin de cinsiyetlerine göre anlamlı şekilde farklılaştığ1 görülmektedir $\left(\boldsymbol{t}_{(\mathbf{3 7 2})}=-3.840, \mathrm{p}=0.000\right)$. Ortalamalar incelendiğinde kadınların ortalamasının $(\overline{\boldsymbol{X}}=49.38)$ erkeklerin ortalamasından daha yüksek olduğu $(\overline{\boldsymbol{X}}=47.19)$; ortalamadaki söz konusu bu fark için hesaplanan etki büyüklüğünün de küçük düzeyde olduğu anlaşılmaktadır.

Sınıf öğretmeni adaylarının sözel beceri, okuma ve yazma becerisi geliştirme özyeterliklerinin öğrenim gördükleri üniversitelere göre anlamlı bir farklılık gösterip göstermedikleri tek faktörlü ANOVA ile analiz edilmiş ve analiz sonuçları Tablo 4 'te gösterilmiştir.

Tablo 4: Sözel Beceri Geliștirme, Okuma Becerisi Geliștirme ve Yazma Becerisi Geliștirme Özyeterliklerinin Öğrenim Gördükleri Üniversiteye Göre Tek Faktörlü ANOVA Sonuçları

\begin{tabular}{|c|c|c|c|c|c|c|c|}
\hline & $\begin{array}{l}\text { Varyansın } \\
\text { Kaynăğ }\end{array}$ & $\begin{array}{l}\text { Kareler } \\
\text { Toplamı }\end{array}$ & Sd & $\begin{array}{l}\text { Kareler } \\
\text { Ortalaması }\end{array}$ & $\mathbf{F}$ & $\mathbf{p}$ & Cohen d \\
\hline $\begin{array}{l}\text { Sözel } \\
\text { Beceri }\end{array}$ & $\begin{array}{l}\text { Gruplar } \\
\text { aras1 }\end{array}$ & 167.030 & 2 & 83.515 & & & \\
\hline Geliştirme & $\begin{array}{l}\text { Gruplar içi } \\
\text { Toplam }\end{array}$ & $\begin{array}{l}20430.27 \\
20597.957\end{array}$ & $\begin{array}{l}371 \\
373\end{array}$ & 55.070 & 1.517 & 0.221 & - \\
\hline $\begin{array}{l}\text { Okuma } \\
\text { Becerisi }\end{array}$ & $\begin{array}{l}\text { Gruplar } \\
\text { aras1 }\end{array}$ & 82.109 & 2 & 41.054 & & & \\
\hline Geliştirme & $\begin{array}{l}\text { Gruplar içi } \\
\text { Toplam }\end{array}$ & $\begin{array}{l}4840.244 \\
4922.353\end{array}$ & $\begin{array}{l}371 \\
373\end{array}$ & 13.046 & 3.147 & $0.044 *$ & 0.26 \\
\hline $\begin{array}{l}\text { Yazma } \\
\text { Becerisi }\end{array}$ & $\begin{array}{l}\text { Gruplar } \\
\text { aras1 }\end{array}$ & 112.634 & 2 & 56.317 & & & \\
\hline Geliştirme & $\begin{array}{l}\text { Gruplar içi } \\
\text { Toplam }\end{array}$ & $\begin{array}{l}8234.460 \\
8347.094\end{array}$ & $\frac{371}{373}$ & 22.195 & 2.537 & 0.080 & - \\
\hline
\end{tabular}

Tablo 4'e göre adayların sözel beceri geliştirme öz-yeterlikleri $\left(\boldsymbol{F}_{(2,373)}=1.517, \mathrm{p}=0.221\right)$ ve yazma becerisi geliştirme öz-yeterliklerinin $\left(\boldsymbol{F}_{(2,373)}=2.537, \mathrm{p}=0.080\right)$ öğrenim gördükleri 
üniversiteye göre anlamlı bir farklılık göstermediği; okuma becerisi geliştirme öz yeterliklerinin ise öğrenim gördükleri üniversiteye göre anlamlı şekilde farklılaştı̆g 1 söylenebilir $\left(\boldsymbol{F}_{(2,373)}=3.147\right.$, $\mathrm{p}=0.044)$. Farklılığın kaynağını belirlemek için post-hoc testlerinden Tukey testi yapılmış, test sonuçlarına göre A Üniversitesi ve B Üniversitesi öğrencilerinin ortalamaları arasında farklılık olduğu görülmüştür. Ortalamalar incelendiğinde A Üniversitesi öğrencilerinin puanlarının $(\overline{\boldsymbol{X}}=35.55)$ B Üniversitesi öğrencilerinin puanlarından $(\overline{\boldsymbol{X}}=34.27)$ yüksek olduğu belirlenmiştir. Hesaplanan etki büyüklüğü değerlendirildiğinde bu değerin orta olduğu görülmüştür.

3) Araştırmanın Üçüncü Alt Problemine İlişkin Bulgular

Sınıf öğretmeni adaylarının rehberlik etme, öğrenciyi aktifleştirme, düşünmeye teşvik ve alternatif değerlendirme düzeylerinin sözel beceri geliştirme öz yeterlik düzeylerine göre anlamlı bir farklılık gösterip göstermediği tek faktörlü ANOVA ile analiz edilmiş, öğretmen adaylarının rehberlik etme, öğrenciyi aktifleştirme düşünmeye teşvik ve alternatif değerlendirme düzeylerinin sözel beceri geliştirme düzeylerine göre anlamlı şekilde farklılaştığı görülmüştür. Farklılı̆̆ın kaynağını belirleyebilmek için yapılan Tukey testi, ortalamalara ait sonuçlar Tablo 5 'te gösterilmiştir.

Tablo 5: Rehberlik Etme, Öğrenciyi Aktifleştirme, Düşünmeye Teşvik ve Alternatif Değerlendirme Düzeylerinin Sözel Beceri Geliștirme Özyeterlik Düzeylerine Göre Ortalamaları

\begin{tabular}{|c|c|c|c|}
\hline & Grup & $\boldsymbol{X}$ & $\mathbf{S}$ \\
\hline \multirow[t]{3}{*}{ Rehberlik Etme } & Düşük & 32.85 & 4.75 \\
\hline & Orta & 37.08 & 4.59 \\
\hline & Yüksek & 41.44 & 4.33 \\
\hline \multirow[t]{3}{*}{ Öğrenciyi Aktifleştirme } & Düşük & 30.16 & 4.32 \\
\hline & Orta & 33.98 & 4.13 \\
\hline & Yüksek & 37.84 & 3.19 \\
\hline \multirow[t]{3}{*}{ Düşünmeye Teşvik } & Düşük & 24.79 & 3.59 \\
\hline & Orta & 27.79 & 3.68 \\
\hline & Yüksek & 31.81 & 3.22 \\
\hline Alternatif & Düşük & 17.35 & 2.98 \\
\hline \multirow[t]{2}{*}{ Değerlendirme } & Orta & 19.45 & 3.04 \\
\hline & Yüksek & 21.98 & 3.24 \\
\hline
\end{tabular}

Tukey testi sonuçlarına göre tüm alt boyutlarda sözel beceri geliştirme düzeylerine göre adayların puanlarının tüm gruplarda birbirinden farklılaştığı belirlenmiştir. Sözel beceri geliştirme düzeyi arttıkça alt boyutlara ait ortalamaların da yükseldiği görülmüştür. Adayların rehberlik etme, öğrenciyi aktifleştirme, düşünmeye teşvik ve alternatif değerlendirme düzeylerinin sözel beceri geliştirme özyeterlik düzeylerine göre anlamlı bir farklılık gösterip göstermediği tek faktörlü ANOVA ile analiz edilmiş, analiz sonuçları Tablo 6 'da gösterilmiştir. 
Tablo 6: Rehberlik Etme, Öğrenciyi Aktifleștirme, Düşünmeye Teşvik ve Alternatif Değerlendirme Düzeylerinin Sözel Beceri Geliştirme Özyeterlik Düzeylerine Göre Tek Faktörlü ANOVA Sonuçları

\begin{tabular}{|c|c|c|c|c|c|c|c|}
\hline & $\begin{array}{l}\text { Varyansın } \\
\text { Kaynağı }\end{array}$ & $\begin{array}{l}\text { Kareler } \\
\text { Toplamı }\end{array}$ & sd & $\begin{array}{l}\text { Kareler } \\
\text { Ortalaması }\end{array}$ & $\mathbf{F}$ & $\mathbf{p}$ & Cohen d \\
\hline \multirow[t]{2}{*}{$\begin{array}{l}\text { Rehberlik } \\
\text { Etme }\end{array}$} & $\begin{array}{l}\text { Gruplar } \\
\text { aras1 }\end{array}$ & 2470.500 & 2 & 1235.250 & \multirow[t]{2}{*}{59.006} & \multirow[t]{2}{*}{$0.000 *$} & \multirow[t]{2}{*}{0.56} \\
\hline & $\begin{array}{l}\text { Gruplar içi } \\
\text { Toplam }\end{array}$ & $\begin{array}{l}7766.634 \\
10237.134\end{array}$ & $\begin{array}{l}371 \\
373\end{array}$ & 20.934 & & & \\
\hline \multirow[t]{2}{*}{$\begin{array}{l}\text { Öğrenciyi } \\
\text { Aktifleştirme }\end{array}$} & $\begin{array}{l}\text { Gruplar } \\
\text { aras1 }\end{array}$ & 1975.866 & 2 & 987.933 & \multirow[t]{2}{*}{61.677} & \multirow[t]{2}{*}{$0.000 *$} & \multirow[t]{2}{*}{0.58} \\
\hline & $\begin{array}{l}\text { Gruplar içi } \\
\text { Toplam }\end{array}$ & $\begin{array}{l}5942.669 \\
7918.535\end{array}$ & $\begin{array}{l}371 \\
373\end{array}$ & 16.018 & & & \\
\hline \multirow[t]{2}{*}{$\begin{array}{l}\text { Düşünmeye } \\
\text { Teşvik }\end{array}$} & $\begin{array}{l}\text { Gruplar } \\
\text { aras1 }\end{array}$ & 1697.682 & 2 & 848.841 & \multirow[t]{2}{*}{66.014} & \multirow[t]{2}{*}{$0.000 *$} & \multirow[t]{2}{*}{0.60} \\
\hline & $\begin{array}{l}\text { Gruplar içi } \\
\text { Toplam }\end{array}$ & $\begin{array}{l}4770.510 \\
6468.193\end{array}$ & $\begin{array}{l}371 \\
373\end{array}$ & 12.859 & & & \\
\hline \multirow[t]{2}{*}{$\begin{array}{l}\text { Alternatif } \\
\text { Değerlendirme }\end{array}$} & $\begin{array}{l}\text { Gruplar } \\
\text { aras1 } \\
\text { Gruplar içi }\end{array}$ & $\begin{array}{l}727.829 \\
3502.580\end{array}$ & $\begin{array}{l}2 \\
371\end{array}$ & $\begin{array}{l}363.915 \\
9.441\end{array}$ & 38.547 & $0.000 *$ & 0.20 \\
\hline & Toplam & 4230.409 & 373 & & & & \\
\hline
\end{tabular}

Tablo 6'ya göre öğretmen adaylarının rehberlik etme $\left(\boldsymbol{F}_{(2,373)}=59.006, \mathrm{p}=0.000\right)$, öğrenciyi aktifleştirme $\left(\boldsymbol{F}_{(2,373)}=61.677, \mathrm{p}=0.000\right)$, düşünmeye teşvik $\left(\boldsymbol{F}_{(2,373)}=66.014, \mathrm{p}=0.000\right)$ ve alternatif değerlendirme düzeylerinin $\left(\boldsymbol{F}_{(2,373)}=38.547, \mathrm{p}=0.000\right)$ sözel beceri geliştirme düzeylerine göre anlamlı şekilde farklılaştığı söylenebilir. Hesaplanan etki büyüklükleri değerlendirildiğinde alternatif değerlendirme alt boyutunun küçük, diğer tüm alt boyutlardaki etki büyüklüğü değerlerinin geniş olduğu anlaşılmaktadır.

Sınıf öğretmeni adaylarının rehberlik etme, öğrenciyi aktifleştirme, düşünmeye teşvik ve alternatif değerlendirme düzeylerinin okuma becerisi geliştirme özyeterlik düzeylerine göre anlamlı bir farklılık gösterip göstermediği tek faktörlü ANOVA ile analiz edilmiş, rehberlik etme, öğrenciyi aktifleştirme, düşünmeye teşvik ve alternatif değerlendirme düzeyleri okuma becerisi geliştirme düzeylerine göre anlamlı şekilde farklılaştığı görülmüsştür. Farklılığın kaynağını tespit etmek için Tukey testi yapılmış, test sonuçların ait ortalamalar Tablo 7'de verilmiştir.

Tablo 7: Rehberlik Etme, Öğrenciyi Aktifleștirme, Düşünmeye Teşvik ve Alternatif Değerlendirme Düzeylerinin Okuma Becerisi Geliştirme Özyeterlik Düzeylerine Göre Ortalamaları

\begin{tabular}{|c|c|c|c|}
\hline & Grup & $\mathbf{X}$ & $\mathbf{S}$ \\
\hline \multirow[t]{3}{*}{ Rehberlik Etme } & Düşük & 32.76 & 4.55 \\
\hline & Orta & 37.31 & 4.30 \\
\hline & Yüksek & 41.67 & 3.92 \\
\hline \multirow[t]{3}{*}{ Öğrenciyi Aktifleştirme } & Düşük & 30.04 & 4.45 \\
\hline & Orta & 34.19 & 3.74 \\
\hline & Yüksek & 38.10 & 2.63 \\
\hline \multirow[t]{3}{*}{ Düşünmeye Teşvik } & Düşük & 24.75 & 3.82 \\
\hline & Orta & 28.06 & 3.50 \\
\hline & Yüksek & 31.54 & 2.99 \\
\hline \multirow[t]{3}{*}{ Alternatif Değerlendirme } & Düşük & 17.48 & 3.20 \\
\hline & Orta & 19.52 & 2.92 \\
\hline & Yüksek & 21.95 & 3.02 \\
\hline
\end{tabular}


Tablo 7'ye göre tüm alt boyutlarda okuma becerisi geliştirme düzeyi düşük, orta düzeyli ve yüksek olan bireylerin puanlarının tüm gruplarda birbirinden farklılaştı̆̆ 1 belirlenmiştir. Okuma becerisi geliştirme düzeyi arttıkça alt boyutlara ait ortalamaların da yükseldiği görülmüştür. Sınıf öğretmeni adaylarının rehberlik etme, öğrenciyi aktifleştirme, düşünmeye teşvik ve alternatif değerlendirme düzeylerinin okuma becerisi geliştirme özyeterlik düzeylerine göre anlamlı bir farklılık gösterip göstermediği tek faktörlü ANOVA ile analiz edilmiş ve analiz sonuçları Tablo 8'de verilmiştir.

Tablo 8: Rehberlik Etme, Öğrenciyi Aktifleştirme, Düşünmeye Teşvik ve Alternatif Değerlendirme Düzeylerinin Okuma Becerisi Geliştirme Özyeterlik Düzeylerine Göre Tek Faktörlü ANOVA Sonuçları

\begin{tabular}{|c|c|c|c|c|c|c|c|}
\hline & $\begin{array}{l}\text { Varyansın } \\
\text { Kaynağı }\end{array}$ & $\begin{array}{l}\text { Kareler } \\
\text { Toplamı } \\
\end{array}$ & Sd & $\begin{array}{l}\text { Kareler } \\
\text { Ortalaması } \\
\end{array}$ & $\mathbf{F}$ & $\mathbf{P}$ & Cohen d \\
\hline \multirow[t]{2}{*}{ Rehberlik Etme } & $\begin{array}{l}\text { Gruplar } \\
\text { aras1 }\end{array}$ & 3421.101 & 2 & 1710.550 & 93.106 & $0.000 *$ & 0.70 \\
\hline & $\begin{array}{l}\text { Gruplar içi } \\
\text { Toplam }\end{array}$ & $\begin{array}{l}6816.033 \\
10237.134\end{array}$ & $\begin{array}{l}371 \\
373\end{array}$ & 18.372 & & & \\
\hline \multirow[t]{2}{*}{$\begin{array}{l}\text { Öğrenciyi } \\
\text { Aktifleştirme }\end{array}$} & $\begin{array}{l}\text { Gruplar } \\
\text { aras1 }\end{array}$ & 2797.211 & 2 & 1398.605 & 101.318 & $0.000^{*}$ & 0.51 \\
\hline & $\begin{array}{l}\text { Gruplar içi } \\
\text { Toplam }\end{array}$ & $\begin{array}{l}5121.324 \\
7918.535\end{array}$ & $\begin{array}{l}371 \\
373\end{array}$ & 13.804 & & & \\
\hline \multirow[t]{2}{*}{$\begin{array}{l}\text { Düşünmeye } \\
\text { Teşvik }\end{array}$} & $\begin{array}{l}\text { Gruplar } \\
\text { aras1 }\end{array}$ & 1985.853 & 2 & 992.927 & 82.184 & $0.000 *$ & 0.66 \\
\hline & $\begin{array}{l}\text { Gruplar içi } \\
\text { Toplam }\end{array}$ & $\begin{array}{l}4482.339 \\
6468.193\end{array}$ & $\begin{array}{l}371 \\
373\end{array}$ & 12.082 & & & \\
\hline \multirow[t]{2}{*}{$\begin{array}{l}\text { Alternatif } \\
\text { Değerlendirme }\end{array}$} & $\begin{array}{l}\text { Gruplar } \\
\text { aras1 }\end{array}$ & 858.235 & 2 & 429.117 & 47.211 & $0.000^{*}$ & 0.50 \\
\hline & $\begin{array}{l}\text { Gruplar içi } \\
\text { Toplam }\end{array}$ & $\begin{array}{l}3372.174 \\
4230.409 \\
\end{array}$ & $\begin{array}{l}371 \\
373 \\
\end{array}$ & 9.089 & & & \\
\hline
\end{tabular}

$* \mathrm{p}<0.001$

Tablo 8 incelendiğinde adayların rehberlik etme $\left(\boldsymbol{F}_{(2,373)}=93.106, \mathrm{p}=0.000\right)$, öğrenciyi aktifleştirme $\left(\boldsymbol{F}_{(\mathbf{2}, 373)}=101.313, \quad \mathrm{p}=0.000\right)$, düşünmeye teşvik $\left(\boldsymbol{F}_{(\mathbf{2}, 373)}=82.184, \quad \mathrm{p}=0.000\right)$ ve alternatif değerlendirme düzeylerinin $\left(\boldsymbol{F}_{(2,373)}=47.211, \mathrm{p}=0.000\right)$ okuma becerisi geliştirme düzeylerine göre anlamlı şekilde farklılaştığı görülmektedir. Hesaplanan etki büyüklükleri değerlendirildiğinde tüm alt boyutlardaki etki büyüklüğü değerlerinin geniş olduğu anlaşılmaktadır.

Sınıf öğretmeni adaylarının rehberlik etme, öğrenciyi aktifleştirme, düşünmeye teşvik ve alternatif değerlendirme düzeylerinin yazma becerisi geliştirme özyeterlik düzeylerine göre anlamlı bir farklılık gösterip göstermediği tek faktörlü ANOVA ile analiz edilmiştir. Tek faktörlü ANOVA sonuçlarına göre öğretmen adaylarının rehberlik etme, öğrenciyi aktifleştirme, düşünmeye teşvik ve alternatif değerlendirme düzeyleri yazma becerisi geliştirme düzeylerine göre anlamlı şekilde farklılaştığı görülmüştür. Farklılığın kaynağını tespit etmek için Tukey testi yapılmış, test sonuçlarına ait ortalamalar Tablo 9' da verilmişitir. 
Tablo 9: Rehberlik Etme, Öğrenciyi Aktifleştirme, Düşünmeye Teşvik ve Alternatif Değerlendirme Düzeylerinin Yazma Becerisi Geliştirme Özyeterlik Düzeylerine Göre Ortalamaları

\begin{tabular}{lllll}
\hline & Grup & & $\boldsymbol{X}$ & $\mathbf{S}$ \\
\hline Rehberlik Etme & Düşük & 32.66 & 4.20 \\
& Orta & 37.02 & 4.67 \\
& Yüksek & 40.97 & 4.61 \\
Öğrenciyi Aktifleştirme & Düşük & 29.96 & 3.96 \\
& Orta & 33.93 & 4.18 \\
& Yüksek & 37.44 & 3.52 \\
Düşünmeye Teşvik & Düşük & 24.74 & 3.34 \\
& Orta & 27.83 & 3.82 \\
& Yüksek & 31.04 & 3.55 \\
Alternatif & Düşük & 17.15 & 2.93 \\
Değerlendirme & Orta & 19.48 & 3.02 \\
& Yüksek & 21.60 & 3.35 \\
\hline
\end{tabular}

Tablo 9 incelendiğinde tüm alt boyutlarda yazma becerisi geliştirme düzeyi düşük, orta düzeyli ve yüksek olan bireylerin puanlarının tüm gruplarda birbirinden farklılaştı̆̆g görülmüştür. Bu bağlamda yazma becerisi geliştirme düzeyi arttıkça alt boyutlara ait ortalamaların da yükseldiği söylenebilir. Sınıf öğretmeni adaylarının rehberlik etme, öğrenciyi aktifleştirme, düşünmeye teşvik ve alternatif değerlendirme düzeylerinin yazma becerisi geliștirme özyeterlik düzeylerine göre anlamlı bir farklılık gösterip göstermediği tek faktörlü ANOVA ile analiz edilmiş, analiz sonuçları Tablo 10'da gösterilmiştir.

Tablo 10: Rehberlik Etme, Öğrenciyi Aktifleştirme. Düşünmeye Teşvik ve Alternatif Değerlendirme Düzeylerinin Yazma Becerisi Geliştirme Özyeterlik Düzeylerine Göre Tek Faktörlü

\begin{tabular}{|c|c|c|c|c|c|c|c|}
\hline & \multicolumn{7}{|c|}{ ANOVA Sonuçları } \\
\hline & $\begin{array}{l}\text { Varyansın } \\
\text { Kaynağı }\end{array}$ & $\begin{array}{l}\text { Kareler } \\
\text { Toplamı }\end{array}$ & Sd & $\begin{array}{l}\text { Kareler } \\
\text { Ortalaması }\end{array}$ & $\mathbf{F}$ & $\mathbf{p}$ & Cohen d \\
\hline \multirow[t]{3}{*}{ Rehberlik Etme } & Gruplar & 2420.117 & 2 & 1210.058 & 57.430 & $0.000 *$ & 0.55 \\
\hline & Gruplar içi & 7817.017 & 371 & 21.070 & & & \\
\hline & Toplam & 10237.134 & 373 & & & & \\
\hline \multirow[t]{3}{*}{$\begin{array}{l}\text { Öğrenciyi } \\
\text { Aktifleştirme }\end{array}$} & $\begin{array}{l}\text { Gruplar } \\
\text { aras1 }\end{array}$ & 1951.874 & 2 & 975.937 & 60.683 & $0.000 *$ & 0.57 \\
\hline & Gruplar içi & 5966.661 & 371 & 16.083 & & & \\
\hline & Toplam & 7918.535 & 373 & & & & \\
\hline \multirow[t]{3}{*}{$\begin{array}{l}\text { Düşünmeye } \\
\text { Teşvik }\end{array}$} & $\begin{array}{l}\text { Gruplar } \\
\text { aras1 }\end{array}$ & 1409.448 & 2 & 704.724 & 51.683 & $0.000^{*}$ & 0.53 \\
\hline & Gruplar içi & 5058.745 & 371 & 13.635 & & & \\
\hline & Toplam & 6468.193 & 373 & & & & \\
\hline \multirow[t]{3}{*}{$\begin{array}{l}\text { Alternatif } \\
\text { Değerlendirme }\end{array}$} & $\begin{array}{l}\text { Gruplar } \\
\text { aras1 }\end{array}$ & 695.084 & 2 & 347.542 & 36.471 & $0.000^{*}$ & 0.44 \\
\hline & Gruplar içi & 3535.325 & 371 & 9.529 & & & \\
\hline & Toplam & 4230.409 & 373 & & & & \\
\hline
\end{tabular}

*p $<0.001$

Tablo 10 incelendiğinde adayların rehberlik etme $\left(\boldsymbol{F}_{(2,373)}=57.430, \mathrm{p}=0.000\right)$, öğrenciyi aktifleştirme $\left(\boldsymbol{F}_{(2,373)}=60.683, \mathrm{p}=0.000\right)$, düşünmeye teşvik $\left(\boldsymbol{F}_{(2,373)}=51.683, \mathrm{p}=0.000\right)$ ve alternatif değerlendirme düzeylerinin $\left(\boldsymbol{F}_{(\mathbf{2}, 373)}=36.471, \mathrm{p}=0.000\right)$ yazma becerisi geliştirme düzeylerine göre anlamlı şekilde farklılaştığı görülmektedir. Hesaplanan etki büyüklükleri değerlendirildiğinde tüm alt boyutlardaki etki büyüklüğü değerlerinin geniş olduğu anlaşılmaktadır. 
4) Araştırmanın Dördüncü Alt Problemine İlişkin Bulgular

Adayların yapılandırmacı yaklaşımı uygulama öz yeterliklerinin sözel beceri geliştirme öz yeterliklerini anlamlı şekilde yordayıp yordamadığını belirlemek amacıyla çoklu regresyon analizi yapılmış, analiz sonuçları Tablo 11'de verilmiştir.

Tablo 11: Bireylerin Yapılandırmacı Yaklaşımı Uygulama Özyeterliklerinden Sözel Beceri Geliştirme Özyeterliklerinin Yordanmasına İlişkin Regresyon Sonuçları

\begin{tabular}{|c|c|c|c|c|c|c|c|}
\hline Değişken & B & Std. Hata $_{B}$ & B & $\mathbf{T}$ & $\mathbf{p}$ & İkili $\mathbf{r}$ & Kısmi R \\
\hline Sabit & 32.714 & 2.29 & - & 14.27 & $0.000 * *$ & - & - \\
\hline Rehberlik Etme & 0.461 & 0.140 & 0.325 & 30.29 & $0.001 *$ & 0.606 & 0.169 \\
\hline $\begin{array}{l}\text { Öğrenciyi } \\
\text { Aktifleştirme }\end{array}$ & 0.324 & 0.133 & 0.201 & 20.43 & $0.016^{*}$ & 0.586 & 0.126 \\
\hline Düşünmeye Teşvik & 0.456 & 0.161 & 0.256 & 20.83 & $0.005^{*}$ & 0.589 & 0.146 \\
\hline $\begin{array}{l}\text { Alternatif } \\
\text { Değerlendirme } \\
\mathrm{R}=0.631\end{array}$ & $\begin{array}{l}-0.308 \\
\boldsymbol{R}^{2}=0.398\end{array}$ & 0.165 & - & -10.87 & 0.062 & 0.481 & -0.097 \\
\hline $\boldsymbol{F}_{(\mathbf{4}, \mathbf{3 6 9})}=61.100$ & $\begin{array}{l}\mathrm{p}=0.000^{*} \\
*\end{array}$ & & & & & & \\
\hline
\end{tabular}

Yordayıcı ve yordanan değişken arasındaki korelasyonlar incelendiğinde, adayların sözel beceri geliştirme öz yeterlik puanları ile rehberlik etme puanları arasında pozitif orta düzeyli bir ilişki olduğu ( $\mathrm{r}=0.606)$, diğer değişkenler kontrol edildiğinde değişkenler arasındaki korelasyonun 0.169 olduğu; sözel beceri geliştirme özyeterlik puanları ile öğrenciyi aktifleştirme puanları arasında pozitif orta düzeyli bir ilişki olduğu ( $\mathrm{r}=0.586)$, diğer değişkenler kontrol edildiğinde değişkenler arasındaki korelasyonun 0.126 olduğu görülmektedir. Yine adayların sözel beceri geliştirme öz yeterlik puanları ile düşünmeye teşvik puanları arasında pozitif orta düzeyli bir ilişki olduğu $(\mathrm{r}=0.589)$, diğer değişkenler kontrol edildiğinde değişkenler arasındaki korelasyonun 0.146 olduğu; sözel beceri geliştirme öz yeterlik puanları ile alternatif değerlendirme puanları arasında pozitif orta düzeyli bir ilişki olduğu $(\mathrm{r}=0.481)$, diğer değişkenler kontrol edildiğinde değişkenler arasındaki korelasyonun 0.097 olduğu görülmektedir. Rehberlik etme, öğrenciyi aktifleştirme, düşünmeye teşvik ve alternatif değerlendirme değişkenleri ile sözel beceri geliştirme özyeterlik değişkeni orta düzeyde anlamlı bir ilişski göstermektedir. $\left(\mathrm{R}=0.631, \boldsymbol{R}^{2}=0.398, \mathrm{p}=0.000\right)$. Rehberlik etme, öğrenciyi aktifleştirme, düşünmeye teşvik ve alternatif değerlendirme, sözel beceri geliştirme öz yeterlik düzeyindeki toplam varyansın yaklaşık olarak \%40'ını açılamaktadır. Standardize edilmiş regresyon katsayılarına ( $\beta$ ) göre, yordayıcı değişkenlerin bireylerin sözel beceri geliştirme özyeterlik düzeyleri üzerindeki önem sıras1 rehberlik etme, düşünmeye teşvik, öğrenciyi aktifleştirme ve alternatif değerlendirme şeklindedir. Regresyon katsayılarının anlamlılık düzeyleri için t-testi sonuçlarına bakılmış, rehberlik etme, düşünmeye teşvik ve öğrenciyi aktifleştirme değişkenlerinin sözel beceri geliştirme öz-yeterlik düzeyleri üzerinde anlamlı birer yordayıcı olduğu, alternatif değerlendirme değişkenin ise anlamlı bir yordayıcı olmadığı görülmüştür. Yapılan çoklu regresyon analizine göre, duyarlılığın yordanmasına ilişkin regresyondenklemi aşağıda verilmiştir. Sözel beceri geliştirme özyeterliğ $\mathrm{i}=32.714+0.461 *($ Rehberlik etme) $+0.456 *$ (düşünmeye teşvik) $+0.324 *$ (öğrenciyi aktifleştirme)-0.308 Bireylerin yapılandırmacıyaklaşımı uygulama öz yeterliklerinin okuma becerisi geliştirme öz-yeterliklerini anlamlı şekilde yordayıp yordamadığını belirlemek amacıyla çoklu regresyon analizi yapılmış, analiz sonuçları Tablo 12' de verilmiştir. 
Tablo 12: Bireylerin Yapılandırmacı Yaklaşımı Uygulama Özyeterliklerinden Okuma Becerisi Geliştirme Özyeterliklerinin Yordanmasına İlişkin Regresyon Sonuçları

\begin{tabular}{|c|c|c|c|c|c|c|c|}
\hline Değişken & B & Std. Hata ${ }_{B}$ & B & $\mathbf{T}$ & $\mathbf{P}$ & İkili $\mathbf{r}$ & Kismi R \\
\hline Sabit & 25.467 & 1.419 & - & 17.95 & $0.000 * *$ & - & - \\
\hline Rehberlik Etme & 0.272 & 0.087 & 0.302 & 3.135 & $0.002 *$ & 0.623 & 0.161 \\
\hline $\begin{array}{l}\text { Öğrenciyi } \\
\text { Aktifleştirme }\end{array}$ & 0.325 & 0.083 & 0.316 & 3.929 & $0.000 * *$ & 0.627 & 0.200 \\
\hline Düşünmeye Teşvik & 0.224 & 0.100 & 0.197 & 2.242 & $0.026^{*}$ & 0.597 & 0.116 \\
\hline $\begin{array}{l}\text { Alternatif } \\
\text { Değerlendirme }\end{array}$ & -0.208 & 0.102 & -0.148 & -2.043 & $0.042 *$ & 0.492 & -0.106 \\
\hline $\mathrm{R}=0.656$ & $\boldsymbol{R}^{2}=0.431$ & & & & & & \\
\hline $\boldsymbol{F}_{(\mathbf{4}, \mathbf{3 6 9})}=69.850$ & $\begin{array}{l}\mathrm{p}=0.000^{*} \\
*\end{array}$ & & & & & & \\
\hline
\end{tabular}

Yordayıc1 yordanan değişkenler arasındaki incelendiğinde, bireylerin okuma becerisi geliştirme öz yeterlik puanları ile rehberlik etme puanları arasında pozitif orta düzeyli bir ilişki olduğu $(\mathrm{r}=0.623)$, diğer değişkenler kontrol edildiğinde değişkenler arasındaki korelasyonun 0.161 olduğu görülmektedir. Bireylerin okuma becerisi geliştirme öz yeterlik puanları ile öğrenciyi aktifleştirme puanları arasında pozitif orta düzeyli bir ilişki olduğu (r=0.627), diğer değişkenler kontrol edildiğinde değişkenler arasındaki korelasyonun 0.200 olduğu görülmektedir. Bireylerin okuma becerisi geliştirme öz yeterlik puanları ile düşünmeye teşvik puanları arasında pozitif orta düzeyli bir ilişki olduğu ( $r=0.597)$, diğer değişkenler kontrol edildiğinde değişkenler arasındaki korelasyonun 0.116 olduğu görülmektedir. Bireylerin okuma becerisi geliştirme öz yeterlik puanları ile alternatif değerlendirme puanları arasında pozitif orta düzeyli bir ilişki olduğu $(r=0.492)$, diğer değişkenler kontrol edildiğinde değişkenler arasındaki korelasyonun - 0.106 olduğu görülmektedir.

Rehberlik etme, öğrenciyi aktifleştirme, düşünmeye teşvik ve alternatif değerlendirme değiş̧kenleri ile okuma becerisi geliştirme öz-yeterlik değişkeni orta düzeyde anlamlı bir ilişki göstermekte $\left(\mathrm{R}=0.656, \boldsymbol{R}^{2}=0.431, \mathrm{p}=0.000\right)$; öğrenciyi aktifleştirme rehberlik etme, düşünmeye teşvik ve alternatif değerlendirme, okuma becerisi geliştirme özyeterlik düzeyindeki toplam varyansın yaklaşık olarak \%43'ünü açıklamaktadır. Standardize edilmiş regresyon katsayılarına ( $\beta$ ) göre, yordayıcı değişkenlerin bireylerin okuma becerisi geliştirme öz yeterlik düzeyleri üzerindeki önem sırası öğrenciyi aktifleştirme, rehberlik etme, düşünmeye teşvik ve alternatif değerlendirme şeklindedir. Regresyon katsayılarının anlamlılık düzeylerine ise t-testi sonuçlarına göre bakılmış öğrenciyi aktifleştirme, rehberlik etme, düşünmeye teşvik ve alternatif değerlendirme değişkenlerinin okuma becerisi geliştirme özyeterlik düzeyleri üzerinde anlamlı birer yordayıcı olduğu görülmüştür. Yapılan çoklu regresyon analizine göre, duyarlılığın yordanmasına ilişkin regresyon denklemi aşağıda verilmiştir. Okuma becerisi geliştirme özyeterliği $=25.467+0.272 *($ Rehberlik etme) $+0.325 *$ (düşünmeye teşvik) $+0.224 *$ (öğrenciyi aktifleştirme)-0.208*(Alternatif değerlendirme) Bireylerin yapılandırmacı yaklaşım uygulama öz yeterliklerinin yazma becerisi geliştirme özyeterliklerini anlamlı şekilde yordayıpyordamadığını belirlemek amacıyla çoklu regresyon analizi yapılmış, analiz sonuçları Tablo 13 'te verilmiştir. 
Tablo 13: Adayların Yapılandırmacı Yaklaşımı Uygulama Öz Yeterliklerinden Yazma Becerisi Geliştirme Özyeterliklerinin Yordanmasına İlişkin Regresyon Sonuçları

\begin{tabular}{|c|c|c|c|c|c|c|c|}
\hline Değişken & B & Std. Hata $_{B}$ & B & $\mathbf{T}$ & $\mathbf{P}$ & İkili $\mathbf{r}$ & Kismi R \\
\hline Sabit & 19.591 & 1.188 & - & 16.493 & $\begin{array}{l}0.000^{*} \\
*\end{array}$ & - & - \\
\hline Rehberlik Etme & 0.172 & 0.073 & 0.248 & 2.366 & $0.018 *$ & 0.543 & 0.122 \\
\hline $\begin{array}{l}\text { Öğrenciyi } \\
\text { Aktifleştirme }\end{array}$ & 0.205 & 0.069 & 0.260 & 2.963 & $0.003^{*}$ & 0.543 & 0.152 \\
\hline Düşünmeye Teşvik & 0.146 & 0.084 & 0.167 & 1.748 & 0.081 & 0.523 & 0.091 \\
\hline $\begin{array}{l}\text { Alternatif } \\
\text { Değerlendirme } \\
\mathrm{R}=0.569\end{array}$ & $\begin{array}{l}-0.097 \\
\boldsymbol{R}^{2}=0.324\end{array}$ & 0.085 & -0.090 & -1.139 & 0.255 & 0.440 & -0.059 \\
\hline $\boldsymbol{F}_{(\mathbf{4}, \mathbf{3 6 9})}=44.154$ & $\begin{array}{l}\mathrm{p}=0.000 * \\
*\end{array}$ & & & & & & \\
\hline
\end{tabular}

Yordayıcı ve yordanan değişkenler arasındaki korelasyonlar incelendiğinde, adayların yazma becerisi geliştirme öz yeterlikpuanları ile rehberlik etme puanları arasında pozitif orta düzeyli bir ilişki olduğu $(\mathrm{r}=0.543)$ diğer değişkenler kontrol edildiğinde değişkenler arasındaki korelasyonun 0.122 olduğu görülmektedir. Bireylerin yazma becerisi geliştirme öz yeterlikpuanları ile öğrenciyi aktifleştirme puanları arasında pozitif orta düzeyli bir ilişki olduğu $(\mathrm{r}=0.543)$, diğer değişkenler kontrol edildiğinde değişkenler arasındaki korelasyonun 0.152 olduğu görülmektedir. Adayların yazma becerisi geliştirme özyeterlik puanları ile düşünmeye teşvik puanları arasında pozitif orta düzeyli bir ilişki olduğu (r=0.523), diğer değişkenler kontrol edildiğinde değişkenler arasındaki korelasyonun 0.091 olduğu görülmektedir. Adayların yazma becerisi geliştirme özyeterlik puanları ile alternatif değerlendirme puanları arasında pozitif orta düzeyli bir ilişki olduğu $(\mathrm{r}=0.440)$, diğer değişkenler kontrol edildiğinde değişkenler arasındaki korelasyonun -0.059 olduğu görülmektedir Rehberlik etme, öğrenciyi aktifleştirme, düşünmeye teşvik ve alternatif değerlendirme değişkenleri ile yazma becerisi geliştirme özyeterlik değişkeni orta düzeyde anlamlı bir ilişki göstermekte $\left(\mathrm{R}=0.569, \boldsymbol{R}^{2}=0.324, \mathrm{p}=0.000\right)$; öğrenciyi aktifleştirme rehberlik etme, düşünmeye teşvik ve alternatif değerlendirme, yazma becerisi geliştirme özyeterlik düzeyindeki toplam varyansın yaklaşık olarak \%32'sini açıklamaktadır. Standardize edilmiş regresyon katsayılarına ( $\beta$ ) göre, yordayıcı değişkenlerin bireylerin yazma becerisi geliştirme özyeterlik düzeyleri üzerindeki önem sıras1 öğrenciyi aktifleştirme, rehberlik etme, düşünmeye teşvik ve alternatif değerlendirme şeklindedir. Regresyon katsayılarının anlamlılık düzeylerine ise t-testi sonuçlarına göre bakılmış, öğrenciyi aktifleştirme ve rehberlik etme değişkenlerinin yazma becerisi geliştirme özyeterlik düzeyleri üzerinde anlamlı birer yordayıcı olduğu ancak düşünmeye teşvik ve alternatif değerlendirme değişkenlerinin anlamlı bir yordayıcı olmadığı görülmüştür. Yapılan çoklu regresyon analizine göre, duyarlılığın yordanmasına ilişkin regresyon denklemi aşağıda verilmiştir.

Yazma becerisi geliştirme özyeterliğ $\mathrm{i}=19.591+0.172 *($ Rehberlik etme $)+0.146 *($ Öğrenciyi aktifleştirme).

\section{5) Araştırmanın Beşinci Alt Problemine İlişkin Bulgular}

Bireylerin öğretmemotivasyonlarının sözel beceri geliştirme öz yeterliklerini anlamlı şekilde yordayıpyordamadığını belirlemek amacıyla çoklu regresyon analizi yapılmış, analiz sonuçları Tablo 14 'te verilmiştir. 
Tablo 14: Bireylerin Öğretme Motivasyonlarından Sözel Beceri Geliştirme Özyeterliklerinin Yordanmasına İlişkin Regresyon Sonuçları

\begin{tabular}{|c|c|c|c|c|c|c|c|}
\hline Değişken & B & Std. Hata ${ }_{B}$ & B & $\mathbf{T}$ & $\mathbf{P}$ & İkili r & Kısmi R \\
\hline Sabit & 59.598 & 1.526 & - & 39.062 & $0.000^{* *}$ & - & - \\
\hline İçsel & & & & & & & \\
\hline $\begin{array}{l}\text { Motivasyo } \\
\text { n } \\
\text { Dissal }\end{array}$ & -0.248 & 0.093 & 0.189 & -2.663 & $0.008^{*}$ & 0.108 & -0.137 \\
\hline $\begin{array}{l}\text { Motivasyo } \\
\mathrm{n}\end{array}$ & 0.619 & 0.106 & 0.414 & 5.839 & $0.000^{* *}$ & 0.278 & 0.290 \\
\hline $\mathrm{R}=0.308$ & $\boldsymbol{R}^{2}=0.095$ & & & & & & \\
\hline $\begin{array}{l}\boldsymbol{F}_{(2,371)}=1 \\
9.427\end{array}$ & $\mathrm{p}=0.000 * *$ & & & & & & \\
\hline
\end{tabular}

Yordayıcı ve yordanan değişkenler arasındaki korelasyonlar incelendiğinde, adayların sözel beceri geliştirme özyeterlik puanları ile içsel motivasyon puanları arasında pozitif düşük düzeyli bir ilişki olduğu $(\mathrm{r}=0.108)$ diğer değişkenler kontrol edildiğinde değişkenler arasındaki korelasyonun 0.137 olduğu görülmektedir. Adayların sözel beceri geliştirme öz yeterlik puanları ile dışsal motivasyon puanları arasında pozitif düşük düzeyli bir ilişki olduğu $(\mathrm{r}=0.278)$, diğer değişkenler kontrol edildiğinde değişkenler arasındaki korelasyonun 0.290 olduğu görülmektedir. İçsel motivasyon ve dişsal motivasyon değiş̧kenleri ile sözel beceri geliştirme özyeterlik değişkeni düşük düzeyde anlamlı bir ilişki göstermekte $\left(\mathrm{R}=0.308, \boldsymbol{R}^{2}=0.095, \mathrm{p}=0.000\right)$; içsel ve dişsal motivasyon, sözel beceri geliştirme özyeterlik düzeyindeki toplam varyansın yaklaşık olarak \%10'unu açıklamaktadır. Standardize edilmiş regresyon katsayılarına $(\beta)$ göre, yordayıcı değişkenlerin bireylerin sözel beceri geliştirme özyeterlik düzeyleri üzerindeki önem sırası dişsal motivasyon ve içsel motivasyon şeklindedir. Regresyon katsayılarının anlamlılık düzeyleri için t-testi sonuçları incelenmiş, içsel ve dişsal motivasyon değişkenlerinin sözel beceri geliştirme öz yeterlik düzeyleri üzerinde anlamlı birer yordayıcı olduğu görülmüştür. Yapılan çoklu regresyon analizine göre, duyarlılığın yordanmasına ilişkin regresyon denklemi aşağıda verilmiştir. Sözel beceri geliştirme özyeterliği $=59.598-0.248 *($ İ̧sel motivasyon $)+0.619 *($ Dişsal motivasyon $)$

Bireylerin öğretme motivasyonlarının okuma becerisi geliştirme öz yeterliklerini anlamlı şekilde yordayıp yordamadığını belirlemek amacıyla çoklu regresyon analizi yapılmış, analiz sonuçları Tablo 15'te verilmiştir.

Tablo 15. Bireylerin Öğretme Motivasyonlarından Okuma Becerisi Geliştirme Özyeterliklerinin Yordanmasına İlişkin Regresyon Sonuçları

\begin{tabular}{|c|c|c|c|c|c|c|c|}
\hline Değişken & B & Std. Hata $_{B}$ & B & $\mathbf{T}$ & $\mathbf{p}$ & İkili $\mathbf{r}$ & Kısmi R \\
\hline Sabit & 43.539 & 0.954 & - & 45.615 & $\begin{array}{l}0.000 * \\
*\end{array}$ & - & - \\
\hline $\begin{array}{l}\text { İçsel } \\
\text { Motivasyon }\end{array}$ & -0.243 & 0.058 & $\overline{0} .290$ & -4.173 & $\begin{array}{l}0.000 * \\
*\end{array}$ & 0.067 & -0.212 \\
\hline $\begin{array}{l}\text { Dişsal } \\
\text { Motivasyon } \\
\mathrm{R}=0.355 \\
\boldsymbol{F}_{(\mathbf{2}, \mathbf{3 7 1})}=26.687\end{array}$ & $\begin{array}{l}0.476 \\
\boldsymbol{R}^{2}=0.126 \\
\mathrm{p}=0.000 * *\end{array}$ & 0.066 & 0.499 & 7.173 & $\begin{array}{l}0.000 * \\
*\end{array}$ & 0.291 & 0.349 \\
\hline
\end{tabular}


Yordayıcı ve yordanan değişken arasındaki korelasyonlar incelendiğinde, bireylerin okuma becerisi geliştirme öz-yeterlik puanları ile içsel motivasyon puanları arasında pozitif düşük düzeyli bir ilişki olduğu $(\mathrm{r}=0.067)$ diğer değişkenler kontrol edildiğinde değişkenler arasındaki korelasyonun -0.212 olduğu görülmektedir. Bireylerin okuma becerisi geliştirme öz yeterlik puanları ile dişsal motivasyon puanları arasında pozitif düşük düzeyli bir ilişki olduğu $(r=0.291)$, diğer değişkenler kontrol edildiğinde değişkenler arasındaki korelasyonun 0.349 olduğu görülmektedir. İçsel motivasyon ve dişsal motivasyon değişkenleri ile okuma becerisi geliştirme özyeterlik değiş̧keni düşük düzeyde anlamlı bir ilişki göstermekte $\left(\mathrm{R}=0.355, R^{2}=0.126, \mathrm{p}=0.000\right)$; içsel ve dişsal motivasyon, okuma becerisi geliştirme özyeterlik düzeyindeki toplam varyansın yaklaşık olarak \%13’ünü açıklamaktadır.

Standardize edilmiş regresyon katsayılarına $(\beta)$ göre, yordayıcı değişkenlerin bireylerin okuma becerisi geliştirme özyeterlik düzeyleri üzerindeki önem sırası dişsal motivasyon ve içsel motivasyon şeklindedir. Regresyon katsayılarının anlamlılık düzeyleri için t-testi sonuçları incelenmiş, içsel ve dişsal motivasyon değişkenlerinin okuma becerisi geliştirme özyeterlik düzeyleri üzerinde anlamlı birer yordayıcı olduğu görülmüştür. Yapılan çoklu regresyon analizine göre, duyarlılığın yordanmasına ilişkin regresyon denklemi aşağıda verilmiş̧ir. Okuma becerisi geliştirme özyeterliğ $\mathrm{i}=43.539-0.243 *(\dot{I} c ̧ s e l$ motivasyon $)+0.476 *($ Dişsal motivasyon $)$

Bireylerin öğretme motivasyonlarının yazma becerisi geliştirme özyeterliklerini anlamlı şekilde yordayıp yordamadığını belirlemek amacıyla çoklu regresyon analizi yapılmış, analiz sonuçları Tablo 16'da verilmiştir.

Tablo 16: Adayların Öğretme Motivasyonlarından Yazma Becerisi Geliştirme Özyeterliklerinin Yordanmasına İlişkin Regresyon Sonuçları

\begin{tabular}{|c|c|c|c|c|c|c|c|}
\hline Değişken & B & Std. Hata $_{B}$ & B & $\mathbf{T}$ & $\mathbf{p}$ & İkili r & Kismi R \\
\hline Sabit & 30.869 & 0.739 & - & 41.778 & $0.000 * *$ & - & - \\
\hline İçsel Motivasyon & -0.131 & 0.045 & -0.204 & -2.914 & $0.000^{* *}$ & 0.117 & -0.150 \\
\hline & 0.328 & 0.051 & 0.449 & 6.395 & $0.000 * *$ & 0.302 & 0.315 \\
\hline $\begin{array}{l}\mathrm{R}=0.334 \\
F_{(2,371)}=23.311\end{array}$ & $\begin{array}{l}R^{2}=0.112 \\
\mathrm{p}=0.000^{*} \\
*\end{array}$ & & & & & & \\
\hline
\end{tabular}

Yordayıc1 ve yordanan değişkenler arasındaki korelasyonlar incelendiğinde, bireylerin yazma becerisi geliştirme öz yeterlik puanları ile içsel motivasyon puanları arasında pozitif düşük düzeyli bir ilişki olduğu $(\mathrm{r}=0.117)$ diğer değişkenler kontrol edildiğinde değişkenler arasındaki korelasyonun -0.150 olduğu görülmektedir. Bireylerin yazma becerisi geliştirme özyeterlik puanları ile dışsal motivasyon puanları arasında pozitif orta düzeyli bir ilişki olduğu $(\mathrm{r}=0.302)$, diğer değişkenler kontrol edildiğinde değişkenler arasındaki korelasyonun 0.315 olduğu görülmektedir. İçsel motivasyon ve dişsal motivasyon değişkenleri ile yazma becerisi geliştirme özyeterlik değişkeni düşük düzeyde anlamlı bir ilişki göstermekte $\left(\mathrm{R}=0.334, R^{2}=0.112, \mathrm{p}=0.000\right)$; içsel ve dışsal motivasyon, yazma becerisi geliştirme özyeterlik düzeyindeki toplam varyansın yaklaşık olarak \%11'ini açıklamaktadır.

Standardize edilmiş regresyon katsayılarına $(\beta)$ göre, yordayıcı değişkenlerin bireylerin yazma becerisi geliştirme özyeterlik düzeyleri üzerindeki önem sırası dışsal motivasyon ve içsel motivasyon şeklindedir. Regresyon katsayılarının anlamlılık düzeyleri için ise t-testi sonuçları incelenmiş, içsel ve dişsal motivasyon değişkenlerinin yazma becerisi geliştirme özyeterlik düzeyleri üzerinde anlamlı birer yordayıcı olduğu görülmüştür. Yapılan çoklu regresyon analizine göre, duyarlılığın yordanmasına ilişkin regresyon denklemi aşağıda verilmiştir. 
Yazma becerisi geliştirme özyeterliği $=30.869-0.131 *$ (Içcsel motivasyon) $+0.328 *($ Dışsal motivasyon)

\section{Tartışma Sonuç ve Öneriler}

Sınıf öğretmenlerinin öğrencilerinin dil becerilerini geliștirme yeterlikleri; öğrencilerinin Türkçe dersi başta olmak üzere eğitim öğretim hayatlarını etkileyen önemli bir unsurdur. Öğretmen niteliklerinin öğrenci başarısındaki değişkenliğin \%40'ını açıklıyor olması nedeniyle öğretmenlerin, öğrencilerini akademik ve sosyal açıdan en iyi şekilde yetiştirebilmeleri için eğitim sistemlerindeki değişiklik ve yenilikleri takip etmeleri ve kendilerini de bu yeniliklerle uyumlu bir şekilde yetiştirmeleri gerekmektedir (Darling, Hammond ve Ball, 1998; akt. Açıkgöz, 2006: 268).

Öğretmenin dil becerilerine ilişkin öz yeterlikleri, uyguladığı eğitim yaklaşımını benimseme düzeyi ve öğretme motivasyonun yüksek olması durumunda öğrencilerin sözel beceri, okuma ve yazma becerilerini en iyi şekilde kazanıp eğitim öğretim hayatlarında da etkin bir şekilde kullanmaları beklenmektedir. 2000'li yılların başlarından itibaren ülkemizde uygulanan Yapılandırmacı Öğrenme Yaklaşımı öğrencinin eğitim sürecinde aktif rol aldığı, öğretmenin rehberlik yönünün vurgulandığı, beceri geliştirmenin esas alındığı bir yaklaşımdır. Sınıf öğretmenleri dil becerilerinin öğretimine ilişkin bilgi ve becerilerle birlikte bu yaklaşıma ilişkin bilgi ve becerileri de hizmet öncesi eğitimleri sürecinde kazanabilirler. Hizmet öncesi eğitime nasıl bir motivasyonla geldikleri de bu bilgi ve becerilerin nasıl kazanılacağının bir belirleyicisi olabilir. Bu nedenle sınıf öğretmeni adaylarının sözel beceri, okuma ve yazma becerisi geliştirme öz yeterlikleri ve öğrenme yaklaşımlarına ilişkin özyeterlikleri ile sürecin insani bir boyutu olan öğretme motivasyonuyla ilişkilendirilebilir.

Araştırma bulguları incelendiğinde sonuç olarak; Sınıf öğretmeni adaylarının özyeterlik düzeylerinin belirlemek amacıyla kullanılmış olan SBGÖÖ, OBGÖÖ, YBGÖÖ, YYUÖÖ ve motivasyonlarını belirlemek için kullanılan ÖMÖ puan ortalamaları incelendiğinde sınıf öğretmeni adaylarının özyeterliklerinin ve motivasyonlarının orta düzeyde olduğu söylenebilir. Bu durum sınıf öğretmeni adaylarının temel dil becerilerini geliştirme ve yapılandırmacı yaklaşımı uygulama özyeterliklerinin daha çok geliştirilmesi gerektiğini ortaya koymuştur.

Alanyazında bu araştırmanın bulgularına benzer veya farklı bulgulara ulaşan çalışmalara rastlamak mümkündür Akdağ \& Yıldız (2011)'ın yapmış oldukları araştırmalarında öğretmenlerin "Öğrencilerin Türkçeyi doğru, güzel ve etkili kullanma becerilerini geliştirebilme yeterlikleri" puanları ve "Okuma ve yazma becerilerini geliştirebilme yeterliklerine" ilişkin davranışları "sık sık" yerine getirdikleri sonucuna ulaşmışlardır. Akyılmaz (2018) ise sınıf öğretmeni adaylarının Türkçe öğretimine ilişkin yeterlik algılarını yüksek bulurken; Oğuz (2009) öğretmen adaylarının sözlü ve yazılı anlatım becerilerine ilişsin yetersiz olduğu sonucuna ulaşmıştır. Bu bulgular araştırma sonucu ile farklılık göstermektedir. Akdağ \& Yıldız (2011) ile Akyılmaz (2018) 'ın çalışmaları sınıf öğretmenlerinin dil becerilerini geliştirmede araştırma sonucuna göre daha yüksek öz yeterliğe sahip olduğu sonucuna ulaşırken; Oğuz (2009)'un çalışması ise öğretmen adaylarının araştırma sonucuna göre daha düşük öz yeterliğe sahip olduğunı göstermektedir. Eğitim öğretimin temelini oluşturan sınıf öğretmenlerinin temel dil becerilerini yeterli düzeyde geliştirme öz yeterliğine sahip olması niteliksiz öğrenme ortamlarına sebep olacağından, öğretmen adaylarının beceri geliştirme öz yeterliklerini geliştirebilecekleri imkânlar yaratılmalıdır.

Öğretmen adaylarının orta düzey bulunan yapılandırmacı yaklaşımı uygulama öz yeterliği ile ilgili olarak alanyazında farklı çalışmalara rastlamak mümkündür. Özenç (2009) sınıf öğretmenlerinin yapılandırmacı yaklaşımi uygulama konusunda kendilerini yeterli görüdükleri sonucuna ulaşmıştır. Kaya (2013) öğretmenlerin yapılandırmacı yaklaşımı uygulamaya ilişkin öz yeterlik inançlarının yüksek olduğu sonucuna ulaşmıştır. Öğrenenin merkezde olduğu bu yaklaşımda öğrenme- öğretme sürecinin kalitesi açısından öğretmenlerin mevcut yaklaşıma yönelik yeterliliği önemli bir faktör olarak görülmektedir. Bu nedenle öğretmen adaylarının orta düzeyde olduğu tespit 
edilen yapılandırmacı yaklaşımı uygulama özyeterliklerinin yeterli düzeye çıkarılabilmesi için hizmet öncesi eğitim süreci yeniden yapılandırılabilir.

Öğretme motivasyonuna ilişkin alanyazın incelendiğinde İlğan vd. (2018) çalışmalarında öğretmenlerin motivasyon düzeyleri yüksek bulunmuş; Erdem \& Gözel (2014)'in çalışmasında ise öğretmenlerin mesleğine motive oldukları sonucunu ortaya konmuştur. Araştırma sonucunda orta düzey bulunan öğretmen adaylarının öğretme motivasyonu alanyazın sonuçlarına göre daha yetersiz kalmaktadır. Öğretmenlerin motivasyonları birçok öğrencinin başarısının çerçevesini çizmesi bakımından da önemlidir.

Sözel beceri geliştirme, okuma, yazma becerisi geliştirme özyeterliklerinin cinsiyetlerine göre anlamlı şekilde farklılaştığı görülmektedir $\left(t_{(372)}=-2.373, \mathrm{p}=0.015\right)$. Kadın sınıf öğretmeni adaylarının sözel beceri geliştirme, okuma, yazma becerisi geliştirme öz yeterliklerinin $(\bar{X}=68.21)$ erkek sınıf öğretmeni adaylarının özyeterliklerinden $(\bar{X}=66.06)$ istatistiki açıdan anlamlı bir şekilde daha yüksek olduğu bulgulanmıştır. Bu farklılığın sebebi kadınların erkeklere göre dil becerilerine daha hâkim olmaları ve dolayısıyla daha ilgili olmalarıyla açıklanabilir. Araştırmaya benzer olarak, sınıf öğretmeni adaylarının Türkçe öğretimineilişkin yeterlik algılarının incelendiği araştırmada cinsiyet değişkenine göre anlamlı bir farklılaşma bulunmuştur. Çalışma sonunda erkek öğretmen adaylarının kadın adaylara göre daha düşük özyeterliğe sahip olduğu tespit edilmiştir (Akyılmaz, 2018). Özdemir ve Erdoğan'nın (2017) çalışmasında da kadın öğretmen adaylarının erkek adaylara göre daha yüksek ilkokuma yazma öğretimi yeterlik inancına sahip olduğu görülmüștür. Benzer şekilde Aşkın (2012)'ın çalışmasında kadın öğretmen adaylarının öz yeterliklerinin erkek sınıf öğretmeni adaylarına göre yüksek olduğu sonucuna ulaşılmıştır. Gerez ve Taşkın öğretmen adaylarının dinleme, okuma, konuşma, yazılı anlatım, öz yeterliklerinin kadınlar lehinde farklılaştığ 1 sonucuna ulaşmışlardır. Alanyazında erkeklerin lehine farklılık gösteren ( Demirtaş, Cömert \& Özer, 2011) ya da cinsiyete göre farklılaşma göstermeyen (Akbaş \& Çelikkaleli, 2006; Berkant ve Ekici, 2007;Aksu, 2008; Kurudayığlu \& Kana, 2013; Akdağ \& Yıldız,2011) çalışmalar da vardır. Ancak öğretime ilişkin yeterlik konusunda sonuçlar çoğunlukla kadın öğretmenler /öğretmen adayları lehine görünmektedir.

Sınıf öğretmeni adaylarının sözel beceri geliştirme, yazma becerisi geliştirme özyeterliklerinin öğrenim görülen üniversiteye göre anlamlı farklılık göstermediği fakat okuma becerisi geliştirme öz yeterliklerinin öğrenim görülen üniversiteye göre anlamlı farklılık gösterdiği görülmektedir. $\left(F_{(2,373)}=3.147, \quad \mathrm{p}=0.044\right)$. A Üniversitesi'nde öğrenim gören sinıf öğretmeni adaylarının okuma becerisi geliştirme özyeterliklerinin $(\bar{X}=35.55)$ B Üniversitesinde öğrenim gören sınıf öğretmeni adaylarının okuma becerisi geliştirme özyeterliklerinden $(\bar{X}=34.27)$ istatiksel olarak anlamlı şekilde daha yüksek olduğu söylenebilir. Alanyazında öğretmenlerin temel dil becerilerini geliştirme öz yeterliklerini üniversite değişkenine göre yordayan çalışmaya ratlanmamıştır. Bu bakımdan sonucun alana katk1 sağlayacağı düşünülmektedir.

Sınıf öğretmeni adaylarının yapılandırmacı yaklaşımı uygulama öz yeterliklerinin rehberlik etme, öğrenciyi aktifleştirme, düşünmeye teşvik ve alternatif değerlendirme düzeylerinin sözel beceri, okuma becerisi, yazma becerisi geliştirme özyeterlik düzeylerine göre anlamlı şekide farklılaştıkları görülmüştür. Tüm alt boyutlarda sözel beceri geliştirme, okuma becerisi geliştirme, yazma becerisi geliştirme düzeyleri düşük, orta düzeyli ve yüksek olan bireylerin puanlarının tüm gruplarda birbirinden farklılaştığı belirlenmiştir. Bu bağlamda sözel beceri, okuma, yazma, becerileri geliştirme özyeterlik düzeyi yüksek olan bir sınıf öğretmeni adayının rehberlik etme, öğrenciyi aktifleştirme, düşünmeye teşvik ve alternatif değerlendirme düzeylerinin de yüksek olacağ söylenebilir. Ayrıca sınıf öğretmeni adaylarının yapılandırmacı yaklaşımı uygulama özyeterliklerinin sözel beceri, okuma becerisi, yazma becerisi geliştirme özyeterliklerini anlamlı şekilde yordadığı; rehberlik etme $(\mathrm{r}=0.606)$, öğrenciyi aktifleştirme $(\mathrm{r}=0.586)$, düşünmeye teşvik(r=0.589), ve alternatif değerlendirme $(\mathrm{r}=0.481)$, değişkenleri ile sözel beceri geliştirme 
özyeterlik değişkeninin orta düzeyde anlamlı bir ilişki içinde olduğu görülmektedir $(\mathrm{R}=0.631$, $R^{2}=0.398, \mathrm{p}=0.000$ ).

Yazma becerisi geliştirme özyeterlik düzeyleri önem düzeyine göre öğrenciyi aktifleştirme $(\mathrm{r}=0.543)$, rehberlik etme $(\mathrm{r}=0.543)$, düşünmeye teşvik $(\mathrm{r}=0.523)$, ve alternatif değerlendirme $(\mathrm{r}=0.440)$ olarak sıralanmaktadır. Regresyon katsayılarının anlamlılık düzeylerine göre ise $\mathrm{t}$-testi sonuçları incelendiğinde, öğrenciyi aktifleştirme, rehberlik etme değişkenlerinin yazma becerisi geliştirme öz yeterlik düzeyleri üzerinde anlamlı birer yordayıcı olduğu ancak düşünmeye teşvik ve alternatif değerlendirme değişkenlerinin anlamlı bir yordayıcı olmadığı görülmüştür $(R=0.569$, $R^{2}=0.324, \mathrm{p}=0.000$ ).

Okuma becerisi geliştirme özyeterlik düzeyleri üzerindeki önem sırası öğrenciyi aktifleştirme $(\mathrm{r}=0.627)$, rehberlik etme $(\mathrm{r}=0.623)$, düşünmeye teşvik $(\mathrm{r}=0.597)$ ve alternatif değerlendirme $(\mathrm{r}=0.492)$, şeklindedir. Regresyon katsayılarının anlamlılık düzeylerine ise $\mathrm{t}$-testi sonuçları incelenmiş, öğrenciyi aktifleştirme, rehberlik etme, düşünmeye teşvik ve alternatif değerlendirme değişkenlerinin okuma becerisi geliştirme öz yeterlik düzeyleri üzerinde anlamlı birer yordayıc1 olduğu görülmüştür $\left(\mathrm{R}=0.656, R^{2}=0.431, \mathrm{p}=0.000\right)$.

Öğretmen adaylarının yapılandırmacı yaklaşımı uygulama alt boyutlarından en çok "öğrenciyi aktifleştirme” boyutunun sözel beceri, okuma, yazma becerisi geliştirme öz yeterliklerini yordadığı, en az ise "alternatif değerlendirme" boyutunun yordadığı söylenebilir. Bu bulgu genel olarak kendilerini yapılandırmacı yaklaşımı uygulama konusunda yeterli gören öğretmenlerin sözel beceri, okuma ve yazma becerisi geliştirmede de kendilerini yeterli bulduklarını şeklinde yorumlanabilir.

Araştırmadan elde edilen bu bulgular Eskici (2013)'nin araştırma bulgularından yapılandırmacı yaklaşımı uygulamada ilkögretim ögretmenlerinin kendilerini en yeterli gördükleri boyutun "ögrenciyi aktifleştirme" en az yeterli gördükleri boyutun "alternatif degerlendirme" boyutu olduğu bulgusunu desteklemektedir.

Sınıf öğretmeni adaylarının öğretme motivasyonlarının sözel beceri geliştirme öz yeterliklerini anlamlı şekilde yordadı $\breve{g} 1,\left(\mathrm{R}=0.308, \mathrm{R}^{2}=0.095, \mathrm{p}=0.000\right)$; bireylerin sözel beceri geliştirme öz yeterlik puanları ile içsel motivasyon puanlarına bakıldığında aralarında pozitif yönde düşük seviyede ilişki bulunduğu(r=0.108) sözel beceri geliştirme öz yeterlik puanları ve dışsal motivasyon puanları $(\mathrm{r}=0.278)$ arasında pozitif düşük seviyede bir ilişki olduğu söylenebilir.

Benzer şekilde adayların öğretme motivasyonlarının okuma becerisi geliştirme özyeterliklerini anlamlı şekilde yordadı $\breve{g} 1,\left(\mathrm{R}=0.355, \mathrm{R}^{2}=0.126, \mathrm{p}=0.000\right)$;bireylerin okuma beceri geliştirme öz yeterlik puanları ile içsel motivasyon puanları aralarında pozitif düşük düzeyli bir ilişkinin bulunduğu ( $\mathrm{r}=0.067)$ okuma becerisi geliştirme özyeterlik puanları ile dışsal motivasyon puanlarına bakıldığında pozitif düşük düzeyli bir ilişkinin( $(r=0.291)$, olduğu görülmektedir.

Yazma becerisi geliştirme özyeterlikleri bağlamında da adayların öğretme motivasyonlarının yazma becerisi geliştirme öz yeterliklerini anlamlı şekilde yordadığ $1,\left(\mathrm{R}=0.334, \mathrm{R}^{2}=0.112, \mathrm{p}=0.000\right)$; sınıf öğretmeni adaylarının yazma becerisi geliştirme özyeterlik puanları ile içsel motivasyon puanları incelendiğinde aralarında pozitif, düşük düzeyli bir ilişki olduğu(r=0.117) yazma becerisi geliştirme özyeterlik puanları ile dışsal motivasyon puanları incelendiğinde aralarında pozitif yönde orta düzeyde ilişkinin olduğu $(\mathrm{r}=0.302)$ görülmektedir.

Araştırmadan elde edilen bu bulgular alanyazında farklı alanlarda yapılan motivasyon ve özyeterlik konulu (Alemdağ vd. 2014; Özşahin, 2019 ) çalışma sonuçlarıyla benzerlik göstermektedir. Araştırma sonuçları öğretme motivasyonlarının beceri geliştirme özyeterliğini etkilediğini ifade etmektedir. 
Sınıf öğretmeni adaylarının meslek yaşamlarında alan bilgilerini pek çok değişkenle birlikte harmanlayıp kullanabilmeleri için motivasyonlarının önemli olduğu söylenebilir (Karakuyu \& Karakuyu,2016). Sınıf öğretmeni adaylarının öğretme motivasyonları temel dil becerilerini geliştirme öz yeterliklerini etkilemektedir. Öğretme motivasyonu düşük olan öğretmenlerin beceri geliştirmeyi ilişkin öz yeterliklerinin de düşük olacağı öğretme motivasyonları yüksek olan sınıf öğretmeni adaylarının sözel beceri, okuma, yazma becerisi geliştirme özyeterliklerinin yüksek olacağ 1 ve sözel beceri,okuma,yazma becerisi geliştirme öz yeterliklerinde dişsal motivasyonun içsel motivasyondan daha etkili olduğu söylenebilir. Sınıf öğretmeni adaylarının içsel motivasyonlarının yükselmesi için mesleki uygulamalara lisans eğitiminin ilk yıllarında başlamalarının etkili olacağı düşünülmektedir. Sınıf öğretmeni adaylarının davranışçı öğrenme anlayışıyla yetişmiş olmalarının dışsal motivasyonlarının içsel motivasyondan yüksek olmasını etkilediği düşünlmektedir.

\section{Kaynakça}

Açıkgöz, K.Ü. (2006). Aktif öğrenme. Biliş Yayınları.

Akbaş, A. \& Çelikkaleli, Ö. (2006). Sınıf öğretmeni adaylarının fen öğretimi özyeterlik inançlarının cinsiyet, öğrenim türü ve üniversitelerine göre incelenmesi, Mersin Üniversitesi Ë̆itim Fakültesi Dergisi, 2(1), 98-110. https://doi.org/10.14582/duzgef.543

Akdağ, M. \& Yıldız, H. (2011), İlköğretim birinci sınıf öğretmenlerinin öğrencilerde dil becerilerini geliştirme yeterliklerine ilişkin görüşleri. Kuramsal Eğitim Bilim, 4(1), 50-70.

Aksu, H. H. (2008). Öğretmen adaylarının matematik öğretimine yönelik öz-yeterlilik inançları, Abant İzet Baysal Üniversitesi Eğitim Fakültesi Dergisi, 8(2), 161-170. https://doi.org/10.17240/aibuefd.2017.17.30227-326612

Akyılmaz, N. (2018). Sınıf ögretmeni adaylarının türkçe ögrretimine ilişkin yeterlik algılarının ve tutumlarının incelenmesi. [Yayınlanmamış Yüksek Lisans Tezi]. Gaziantep Üniversitesi, Eğitim Bilimleri Enstitüsü.

Alemdağ, C., Öncü, E. \& Yılmaz, A.K. (2014). Beden eğitimi öğretmeni adaylarının akademik motivasyon ve akademik öz yeterlikleri. Spor Bilimleri Dergisi, 25(1), 23-35. https://doi.org/10.32706/tusbid.419468

Aşkın, İ. \& Demirel M. (2012) Sınıf öğretmeni adaylarının Türkçe öğretimi yeterliklerine ilişkin görüşleri. Ë̆gitim ve Öğretim Araştırmalart Dergisi, 1(3),178-189. https://doi.org/10.24106/kefdergi.2621

Ayık, A., Akdemir, Ö. A. \& Seçer, İ. (2015). Öğretme motivasyonu ölçeğinin Türkçeye uyarlanması: Geçerlik ve güvenirlik çalışması. Current Research in Education, 1(1), 33-45. https://doi.org/10.29106/fesa.487473

Bandura, A. \& Adams, N. E. (1977). Analysis of self-efficacy theory of behavioral change. Cognitive Therapy and Research, 1(4), 287-310.

Bayat, N. \& Şekercioğlu, G. (2014). Yazma duyarlılığı ölçeğinin psikometrik niteliklerinin belirlenmesi ve yazma duyarlılığının farklı değişkenler açısından incelenmesi. International Journal of Language Academy, 2(3), 283-301. https://doi.org/10.18033/ijla.115

Berkant, H. G. \& Ekici, G. (2007). Sınıf öğretmeni adaylarının fen öğretiminde öğretmen öz yeterlik inanç düzeyleri ile zekâ türleri arasındaki ilişkinin değerlendirilmesi, Çukurova Üniversitesi Sosyal Bilimler Enstitüsü Dergisi, 16(1), 113-132. https://doi.org/10.14520/adyusbd.23034

Büyükkaragöz, S.S. (1998). Öğretmenlik mesleğine giriş. Mikro Yayınları. 
Büyükses, L. (2010) Öğretmenin iş ortamındaki motivasyonunu etkileyen etmenler. [Yayınlanmamış Yüksek Lisans Tezi]. Süleyman Demirel Üniversitesi Sosyal Bilimler Enstitüsü.

Büyüköztürk, Ş., Kılıç Çakmak, E., Akgün, Ö.E., Karadeniz, Ş. \& Demirel, F. (2014). Bilimsel araştırma yöntemleri. Pegem Yayınlanı.

Canbulat, M., Çelenk, S. \& Kutluca Canbulat, A.N. (2004). Almanya ve Türkiye ilköğretim okullarının anadil öğretiminde konuşma ve dinleme becerilerine yaklaşımları, XIII. Ulusal Ĕgitim Bilimleri Kurultayl, 6-9 Temmuz 2004- İönü Üniversitesi, Eğitim Fakültesi.

Demirel, Ö. (1999). İlköğretim okullarında Türkçe öğretimi. Millî Eğitim Yayınları.

Demirtaş, H.,Cömert, M. \& Özer, N. (2011). Öğretmen adaylarının öz yeterlik inançları ve öğretmenlik mesleğine ilişkin tutumları. Eğitim ve Bilim, 36(159), 96-111. https://doi.org/10.21764/maeuefd.651393

Derbedek, H. (2008). İlköğretim Okul müdürlerinin ögretimsel liderlik özelliklerinin ögretmenlerin öz yeterlikleri üzerindeki etkileri Bursa İli Örneği. [Yayınlanmamış Yüksek Lisans Tezi]. Pamukkale Üniversitesi Sosyal Bilimler Enstitüsü.

Erdem, A \& Gözel, E. (2014). Sınıf öğretmeni adaylarının öğretmenlik mesleğine ilişkin motivasyon düzeyleri. Akademik Sosyal Araştırmalar Dergisi, 2(1), 49-60.

Eskici, M. (2013) İlkögretim ögretmenlerin yapılandırmacı yaklaşıma ilişkin öz yeterlik algıları ile tutumları. [Yayınlanmamış Doktora Tezi].Abant İzzet Baysal Üniversitesi Eğitim Bilimleri Enstitüsü.

Evrekli, E., Ören, F.S. \& İnel, D. (2010, 11-13 Kasım). Ögretmen adaylarının yapılandırmacı yaklasımı uygulamaya yönelik öz yeterliliklerinin cinsiyet, bölüm ve sınıf düzeyi degişkenleri açısından incelenmesi. [Sözlü bildiri]. International Conference on NewTrends in Education and Their Implication.

Gerez Taşkın, F. (2015). Türkçe öğretmeni adaylarının dinleme, konuşma, okuma ve yazma öz yeterlikleri ile öğrenme stillerinin incelenmesi Atatürk Üniversitesi örneği. [Yayınlanmamış Yüksek Lisans Tezi]. Atatürk Üniversitesi Eğitim Bilmleri Enstitüsü.

Göçer, A. (2010). Eğitim fakültesi öğrencilerinin yazılı anlatım becerilerinin süreç yaklaşımı ve metinsellik ölçütleri ekseninde değerlendirilmesi (Niğde Üniversitesi Örneği). Kastamonu Eğitim Dergisi, 18(1), 271-290. https://doi.org/10.24106/kefdergi.361826

Güneş, F. (2007, 15-16-17 Kasım) Yapılandırmacı dil yaklaşımı ve Türkçe öğretimi. [Sözlü bildiri]. I.İlköğretim Kongresi, Hacettepe Üniversitesi Eğitim Fakültesi.

Güneş, F. (2009). Türkçe öğretiminde günümüz gelişmeleri ve yapılandırıcı yaklaşım. Mustafa Kemal Üniversitesi Sosyal Bilimler Enstitüsü Dergisi,6(11),1-21. https://doi.org/10.31592/aeusbed.666691

Güneyli, A. (2007). Etkin öğrenme yaklaşımının anadili eğitiminde okuma ve yazma becerilerini geliştirmeye etkisi. [Yayınlanmamış Doktora Tezi]. Ankara Üniversitesi, Sosyal Bilimler Enstitüsü.

Güzel C. D. \& Evin G. İ. (2015). Öğretme motivasyonu ölçeğinin Türkçe’ye uyarlama çalışması. Mehmet Akif Ersoy Üniversitesi Eğitim Fakültesi Dergisi, 36,72-89. https://doi.org/10.21764/maeuefd.329888

İlğan, A., Canoğlu, Ö., Karamert, Ö., \& Şensoy, Ç. P. (2018). Öğretmenlerin çocuk sevme düzeyleri ile öğretme motivasyonları arasındaki ilişkinin incelenmesi. Electronic Turkish Studies, 13(19), 979-1003. https://doi.org/10.7827/turkishstudies.13985 
Karadeniz, B.C. \& Yavuz, C. (2009). Sınıf öğretmenlerinin motivasyonunun iş tatmini üzerine etkisi. Uluslararast Sosyal Araştırmalar Dergisi, 2(9), 507-509.

Karakuyu, Y. \& Karakuyu, A. (2016). Motivasyon ve öz-yeterliğin sınıf öğretmeni adaylarının teknolojik pedagojik alan bilgilerine (tpab) katkısı. Uşak Üniversitesi Ĕ̈itim Araştırmaları Dergisi 2(1), 89- 100. https://doi.org/10.29065/usakead.232415

Karasar, N. (2005). Bilimsel araştırma yöntemi, Nobel Yayıncılık.

Kauffman, D. F., Yılmaz-Soylu, M. \& Duke, B. (2011). Öğretme motivasyonu ölçeğinin geçerlik çalışması. Hacettepe Üniversitesi Eğitim Fakültesi Dergisi, 40, 279-290. https://doi.org/10.23891/yyuni.2017.0

Kavcar, C. \& Oğuzkan, F. ve Sever, S. (1998). Türkçe Öğretimi. Engin Yayınevi.

Kaya, N (2013) Sinıf ögretmenlerinin yapılandırmacılı̆̆a yönelik tutumları ve yapılandırmacılı̆̆ uygulamaya ilişkin öz-yeterlik inançları Afyonkarahisar ili örneği. [Yayınlanmamış Yüksek Lisans Tezi]. Afyon Kocatepe Üniversitesi Sosyal Bilimler Enstitüsü.

Kurudayığlu, M. \& Kana, F. (2013). Türkçe öğretmeni adaylarının dinleme becerisi ve dinleme eğitimi özyeterlik algıları. Mersin Üniversitesi Eğitim Fakültesi Dergisi. 9(2), 245-258. https://doi.org/10.12780/uusbd277

Kutluca Canbulat, A. N. (2017). Classroom teacher candidates' perceptions of teacher self-efficacy in developing students' reading, writing and verbal skills: Scale development study. Educational Research and Reviews, 12(16), 789-800. https://doi.org/10.5897/err2017.3305

MEB, (2015). Türkçe Dersi Öğretim Programı http://web.deu.edu.tr/

MEB, (2017). Öğretmen Yeterlilikleri. http://oygm.meb.gov.tr

MEB (2018). Türkçe Dersi Öğretim Programı. http://web.deu.edu.tr

Oğuz, A. (2009). Öğretmen adaylarının sözlü ve yazılı anlatım becerilerine ilişkin öz yeterlik algıları. Elektronik Sosyal Bilimler Dergisi, 8(30), 18-42. https://doi.org/10.14520/adyusbd.351754

Özdamar, K. (1999). Paket programlar ile istatistiksel veri analizi 1. Kaan Kitabevi.

Özdamar, K. (2004). Paket programlar ile istatistik veri analizi 1. Kaan Kitabevi.

Özdemir, C. \& Erdoğan, T. (2017). Sınıf öğretmeni adaylarının ilk okuma ve yazma öğretimine ilişkin öz yeterlik inançlarının belirlenmesi. Abant İzzet Baysal Üniversitesi Ĕgitim Fakültesi Dergisi, 17(1), 314- 331. https://doi.org/10.17240/aibuefd.2017.17.28551-304637

Özenç, M. (2009) Sınıf ögretmenlerinin yapılandırmacı yaklaşım ile ilgili yeterlik düzeylerinin incelenmesi. [Yayınlanmamış Yüksek Lisans Tezi]. Marmara Üniversitesi Eğitim Bilimleri Enstitüsü.

Özşahin, C. (2019). Öğretmenlerin Sosyal Medya Bă̆imlılı̆̆ı, Öğretmenlik Öz-Yeterlilikleri Ve Motivasyonlari Arasindaki Illişkinin Incelenmesi. [Yayınlanmamış Yüksek Lisans Tezi]. Gaziantep Üniversitesi Eğitim Bilimleri Enstitüsü.

Raykov, T. \& Marcoulides, G. A. (2008). An introductionto applied multivariate analysis (First Edition). NY: Taylor ve Francis Group.

Senemoğlu, N. (1992). İngiltere'de İlköğretime öğretmen yetiştirme ve Türkiye ile karşılaştırılmasıTürkiye'de ilköğretime öğretmen yetiştirmenin geliştirilmesi için bazı öneriler. Hacettepe Üniversitesi Eğitim Fakültesi Dergisi, 8, 143-156. https://doi.org/10.20860/ijoses.488657 
Sever, E. \& Memiş, A. (2013). Süreç temelli yazma modellerinin ilkokul dördüncü sınıf öğrencilerinin yazım-noktalama becerisine ve yazma eğilimine etkisi. Karadeniz Sosyal Bilimler Dergisi, 5(9), 243- 259. https://doi.org/10.31463/aicusbed.586485

Tabak, G. \& Göçer, A. (2014). Dinleme becerisine yönelik alternatif ölçme ve değerlendirme araçları. Bartın Üniversitesi Eğitim Fakültesi Dergisi, 3(2), 250-272. https://doi.org/10.14686/BUEFAD.201428181

Üstüner, M. (2006). Öğretmenlik mesleğine yönelik tutum ölçeğinin geçerlik ve güvenirlik çalışması. Kuram ve Uygulamada Eğitim Yönetimi, 45,109-127.

Yelok, V. S. \& M. Eyyüp S. (2009). Öğretmen adaylarının sözlü anlatım dersine ve sözlü anlatıma yönelik tutumlarının değerlendirilmesi. Türk Eğitim Bilimleri Dergisi, 7(3), 581606. 